\title{
The impact of disclosure reform on
}

\section{the NZX's financial information environment ${ }^{+}$}

\author{
Meng Huang, Alastair Marsden and Russell Poskitt \\ University of Auckland
}

\begin{abstract}
This study investigates the impact of amendments to the New Zealand Exchange's listing rules and the Securities Markets Act 1988 enacted in December 2002. These reforms provided statutory backing for a continuous disclosure listing rule requiring companies to immediately release all price-sensitive information to investors. We follow the methodology employed by Helfin et al. (2003) to test the impact of Regulation FD in the US. Our results show that under New Zealand's continuous disclosure regime analysts' earnings forecast errors did not decline but that analysts' forecasts showed less dispersion in the post-reform period. In respect of informational efficiency, we find a smaller abnormal return around the annual earnings announcement date in the post-reform period for small companies. Our results suggest that the reforms have improved the flow of information to investors, consistent with the intent of the reform.
\end{abstract}

Key words: Securities Market Act, analysts' forecasts, information efficiency, continuous disclosure.

JEL: classification: $G 14, G 38, K 22$

Corresponding author:

Alastair Marsden

Department of Accounting and Finance

University of Auckland

Private Bag 92019

Auckland

a.marsden@auckland.ac.nz

(09) 3737599 ext 88564

\footnotetext{
+ The authors acknowledge the assistance of the NZX and Securities Industry Research Centre for Asia-Pacific (SIRCA) in making available the data used in this study. The authors thank Jerry Bowman, Glenn Boyle, Michael McIntyre and participants at the $10^{\text {th }}$ Annual New Zealand Finance Colloquium, New Zealand Institute for the Study of Competition and Regulation Inc seminar on Continuous Disclosure and the 2006 Asian FA / FMA Finance Conference for helpful comments. All errors are the authors' responsibility.
} 


\section{INTRODUCTION}

During 2002 significant changes were made to the listing rules of the New Zealand Exchange (NZX) and the Securities Market Act 1988. These reforms introduced an enhanced disclosure regime with NZX-listed companies now facing more stringent continuous disclosure listing rules that had statutory backing. The broad aim of these reforms was to enhance investor confidence in the New Zealand equity market by harmonising domestic securities law with international standards (Dalziel, 2002). This paper examines the impact of these reforms on two key measures of the financial information environment: the accuracy of analyst forecasts and the informational efficiency of stock prices. We hypothesise that the reforms should have increased the timeliness of disclosures in the post-reform period, improved analysts' forecasts and moved stock prices more quickly to their full-information level.

This research is significant for several reasons. First, although there have been significant reforms to disclosure regimes in several jurisdictions over the last decade, the empirical evidence on some aspects of these reforms is mixed. For example, prior studies into the effects of the enhanced disclosure reform in Australia (e.g., Brown et al., 1999) and Regulation Fair Disclosure (Reg FD) in the US (e.g., Heflin et al., 2003; Bailey et al., 2003) found no strong evidence that either analysts' forecast error or forecast dispersion improved in the post-reform period. In contrast Irani et al. (2003) found that forecast dispersion increased in the post-reform period following the introduction of Reg FD. Similarly Bailey et al. (2003) report an increase in analyst forecast dispersion post-Reg FD and an increase in other measures of disagreement suggesting post-Reg FD analysts have greater difficulty in forming forecasts. Dubow et al. (2006) report no strong evidence of any fall in the level of insider trading in the UK following the introduction of the Financial Services and Markets Act (FSMA) in 
2001 which made it easier to prosecute breaches of the London Stock Exchanges' listing rules that impose a general obligation on listed companies to provide pricesensitive information to the market in a timely manner and also prohibit the selective disclosure of price-sensitive information. ${ }^{1}$

Second, the empirical results will provide an initial assessment of the impact of the reform package and thus should be of interest to both sides of the regulatory debate in New Zealand and in other jurisdictions that have continuous disclosure requirements or obligations. ${ }^{2}$ Although the Securities Commission argued that the existing disclosure regime was not "international best practice" and in need of reform (Securities Commission, 2002), opponents of the reform package argued that the reforms were unnecessary and that the Government was mistaken in following Australian securities law rather than "best practice" US disclosure regulations (Franks, 2002). Furthermore, in the post-reform period, commentators have called for further refinements to the regulations, arguing that many companies were struggling with the requirement to make timely revisions to earnings forecasts (Gaynor, 2003).

In this study we follow the methodology employed by Helfin et al. (2003) to test the impact of Regulation FD in the US. Specifically we examine analysts' forecast performance and the informational efficiency of stock prices for a sample of NZX-

\footnotetext{
${ }^{1}$ Under Listing Rule 9 listed UK companies must notify the Company Announcements Office of the London Stock Exchange without delay any major new developments that are not public knowledge, any change in financial condition or expectation of performance, impending strategic developments where a breach of confidence may have occurred and other board decisions or announcements where the information may be price-sensitive. See The Financial Services Authority (2000).

${ }^{2}$ The introduction of statutory backing for a continuous disclosure regime is part of the Government's wider securities law reform programme. Reforms to the laws relating to insider trading and market manipulation are currently under discussion.
} 
listed stocks over a two-year period immediately prior to the introduction of the reforms to New Zealand's continuous disclosure regime and a two year period immediately following the introduction of the reforms. Our univariate analysis finds that both analysts' median forecast errors and forecast dispersion are lower in the post-reform period. However when we use regression analysis to control for other factors we find only evidence of a decline in analysts' forecast dispersion in the postreform period; the change in analysts' forecast error is no longer significant.

We also find the size of the stock price adjustments around earnings announcement dates to be lower in the post-reform period. The reduction in the information gap is concentrated in small firms, consistent with the argument that larger firms had betterdeveloped disclosure policies and practices prior to the reform and that the reforms were primarily of benefit to investors in smaller firms. Smaller firms have lower levels of analyst coverage and are generally characterised by higher levels of information asymmetry. Thus the more stringent continuous disclosure regime can be expected to reduce information asymmetry between managers and investors in mainly small stocks.

Our paper contributes to the literature by presenting new evidence on the effects of the disclosure reforms of December 2002. To date the evidence on these reforms is mixed. Poskitt et al. (2005) find that these disclosure reforms had no impact on the level of informed trading in NZX-listed stocks while Frijns et al. (2006) report a decrease in the information asymmetry component of the bid-ask spread for less liquid stocks following the introduction of the enhanced disclosure rules. Research by Dunstan et al. (2005) suggests that, apart from firms expecting negative earnings changes, the disclosure behaviour of NZX-listed firms did not substantially alter in the 
post-reform period. Dunstan et al. (2006), however, also report evidence than market adjusted returns for preliminary earnings announcements diminished in the postreform period. Our study finds evidence of a significant reduction in the dispersion of analysts' forecasts in the post reform period. Similar to Dunstan et al. (2006) we also find a significant improvement in the informational efficiency of stock prices for small stocks ${ }^{3}$.

The remainder of this paper is structured as follows. Section 2 discusses the background to the reforms and the major features of the reform package. Section 3 develops the central hypotheses of the paper and Section 4 reviews the evidence from prior studies. Section 5 outlines the methodology employed. The sample of NZXlisted firms and data are discussed in Section 6. The empirical results are presented in Section 7. Section 8 of the paper concludes.

\section{INSTITUTIONAL BACKGROUND}

During 2002 an enhanced continuous disclosure regime modelled on that of Australia was introduced in New Zealand. This reform involved changes to the listing rules of the NZX and amendments to the Securities Markets Act 1988. These reforms were introduced against a background of dissatisfaction with the regulatory regime governing the operation of the NZX. Successive governments had been prepared to take a light-handed approach to regulation, with the result that the NZX was perceived as an under-regulated market and out of step with international best practice. Both the

\footnotetext{
${ }^{3}$ We use more rigorous sample selection criteria and employ difference control variables compared to Dunstan et al. (2006). In addition our study examines changes in analysts' forecast errors in the post reform period.
} 
Government and the NZX felt that international investor confidence would be enhanced if international investors could identify familiar standards.

To implement the reforms the New Zealand Parliament enacted the Securities Market Amendment Act 2002. This act amended the Securities Market Act 1988, to take effect from 1 December 2002. The amendments introduced a statutory continuous disclosure obligation for NZX-listed companies and set forth substantial penalties for contravention of the NZX's continuous disclosure regulations. Under section 19D of the Securities Market Amendment Act 2002 the continuous disclosure provisions were defined as:

“... provisions that require a public issuer that is a party to a listing agreement with a registered exchange to notify information about events or matters as they arise for the purpose of that information being made available to participants in the registered exchange's market".

Material information was also defined as information that (section 19E of the Securities Market Amendment Act 2002):

"a reasonable person would expect, if it were generally available to the market, to have a material effect on the price or value of quoted securities of the public issuer".

The Securities Market Amendment Act 2002 provided that a listed company in contravention of the amendments to the Securities Market Act 1988 commits an offence and is liable to a fine of up to $\$ 30,000$ by the Securities Commission. In addition the courts could impose pecuniary penalties on the listed company of up to 
$\$ 300,000$ on the application of the Securities Commission if it is satisfied that the company has contravened the regulations. ${ }^{4}$

At the same time as the reforms to the Securities Market Act 1988 were debated in Parliament during 2002 the NZX reviewed its listing rules relating to continuous disclosure. Prior to 2002, Listing Rule 10.1 required a listed company to treat information as an asset, to be used and applied for its overall benefit. Under this approach a listed company was expected to release "relevant information" to the NZX immediately that it ceased to have greater value to the company than for the information to remain confidential (NZX, 2002). The new listing rules were modelled on Listing Rule 3.1 of the Australian Stock Exchange (ASX). One important change was to dispense with the requirement that information be treated as an asset, instead requiring that material (i.e. price-sensitive) information be disclosed immediately, on the presumption that the information belongs to all investors (NZX, 2002). A company could no longer withhold information on the grounds that there was greater value to the company in retaining the information than in disclosure.

Under both the old and new listing rules the NZX still allows "carve-out" provisions and non-disclosure of material information where all the following criteria are satisfied: a reasonable person would not expect the information to be disclosed; the confidentiality of the information is maintained; release of the information would

\footnotetext{
${ }^{4}$ The legislation also included other measures such as the establishment of a co-regulatory framework, with the NZX as a frontline regulator administering the market and the Securities Commission overseeing the market; the tightening of insider trading rules; the establishment of the Securities Commission as a civil enforcement body for insider trading and continuous disclosure; increased powers of inspection by the Securities Commission; the requirement that directors and officers of publicly-listed companies must disclose securities dealings to the NZX within five trading days; and
} 
breach a law or the information relates to an incomplete proposal, is a matter of supposition or is insufficiently definite to warrant disclosure, is generated for internal management purposes, or is a trade secret (NZX Listing Rule 10.1.1).

Under the new listing rules, however, even if the exemptions under the carve-out provisions applied, disclosure is required soon as the relevant information is received by someone who might use it as a basis for trading. Immediate disclosure is also required if necessary to prevent the development or subsistence of a "false market" where prices are set by rumour and misinformation. ${ }^{5}$

\section{HYPOTHESIS DEVELOPMENT}

The theoretical disclosure literature typically views enhanced disclosure regulation as a tool for eliminating the information asymmetry between informed and uninformed investors and the associated transfers of wealth that occur when these two classes of investors trade with each other (e.g., Kim, 1993). The NZX argues that continuous disclosure reduces information costs, assists investors in making informed decisions and enhances confidence in the integrity of the market by removing opportunities for insider trading and the creation of a false market (NZX, 2005).

In this paper we are primarily interested in the impact of the new statutory-backed continuous disclosure regime on two earnings-related aspects of the financial information environment of NZX-listed stocks - the performance of analysts'

increases in penalties under the Securities Act 1978 to bring them into line with other domestic and international business law penalties.

${ }^{5}$ The new listing rules also carried forward the prohibition on selective disclosure of information but with a significant change. Companies are prohibited from disclosing information to the public prior to disclosing the information to the NZX and prior to receiving acknowledgement from the NZX that the information has been received. 
earnings forecasts and price reactions to earnings announcements. We use analysts' earnings forecasts as one measure of the financial information environment because analysts' forecasts are used widely as a proxy for investor beliefs (e.g., Abarbanell et al., 1995). We also use the price reaction around earnings announcements to measure the information gap in the market immediately prior to earnings announcements. Prior research shows that the information content of an earnings announcement is widely anticipated (e.g., Ball et al., 1968; Beaver, 1968). A superior pre-announcement earnings information environment should result in a smaller price reaction around the earnings announcement date.

The intent of the reforms is to encourage more timely disclosure of value-relevant information to investors. We expect this more timely disclosure to improve analysts' forecast accuracy and reduce the disagreement among individual analysts' forecasts. We also expect more timely disclosure to move stock prices closer to their fullinformation post-announcement level during the period immediately prior to the earnings announcement. In summary, our two central hypotheses are:

H1: Analysts' forecast error and dispersion are lower in the post-reform period.

and

$\mathrm{H} 2$ : $\quad$ The information gap is lower in the post-reform period.

Although the arguments for expecting enhanced disclosure to improve the financial information environment appear sound, there are a number of arguments to the contrary. First, the reforms did not constitute a dramatic change. For example, existing securities market legislation proscribed insider trading and elements of a continuous disclosure regime and a prohibition against selective disclosure were already in 
place. ${ }^{6}$ Thus it is quite possible that the research design may be unable to detect any impacts of the reforms.

Second, the hypotheses advanced above are based on one view of how information is produced, processed and impounded into stock prices. Problems with the proposed disclosure regime may include (i) a reduced incentive for brokerage firms to invest in research; (ii) investors being deluged with too much information, and (iii) the critical role played by analysts in the dissemination of information and company research may be undermined. ${ }^{7}$

A policy of more timely disclosures may therefore reduce the incentive for private information search since there is now a greater likelihood that the information will be released to the market before it can be discovered through private search activities (Kim et al., 1991). Thus the disclosure reforms might simply substitute public disclosures for private information production and leave the overall level of information unchanged. ${ }^{8}$

\footnotetext{
${ }^{6}$ The chief executive of the NZX, Mark Weldon, stated: "The [NZX] listing rules .... were basically continuous disclosure rules anyway, in the sense that if something was 'relevant' information you were required to disclose it. Is it a seismic shift? The answer is no. Is it important? The answer is yes. ..... It is important because it makes it slightly more visible and it makes it slightly more certain" (Pankhurst, 2002).

${ }^{7}$ See Wilkinson (2003) for a discussion of some of the reasons why mandatory disclosure is not necessarily a good thing. We also thank Bryce Wilkinson for bringing to our intention that the impacts of the new continuous disclosure rules and the reforms to these rules are also empirical issues and that he did not assert (as suggested in earlier versions of our work) mandatory disclosure would necessarily lead to all these problems.

${ }^{8}$ Moreover, public disclosures provide investors with superior information processing skills the opportunity to process public information into valuable private information (Kim et al., 1994). Thus, to the extent that the enhanced disclosure regime will increase the volume of disclosures, the new regime will give these investors more opportunities to practice, and take advantage of, their unique skills. That is informational asymmetry may worsen and the level of information-based trading may increase.
} 
Critics also observed that one should be careful not to equate more disclosure with better disclosure. One of the fears of the opponents of the reform was that investors may be inundated with a flood of information, much of which would be of little value to analysts and investors. ${ }^{9}$ Retail investors may have neither the time nor the expertise to analyse the expected deluge in additional information and, in the absence of analysis and interpretation by analysts, these investors might make poor investment decisions, potentially resulting in larger price shocks and higher price volatility. ${ }^{10}$

The prohibition on selective disclosure practices, such as providing private guidance to analysts' earnings forecasts, may also threaten to diminish the role that analysts play in ensuring that stocks are priced efficiently. In addition impeding the flow of new information to analysts would hamper the process by which informed traders and analysts' clients incorporated new information into prices, and thereby reduce market efficiency and pricing of stocks at their true fundamental value. ${ }^{11}$

Gaynor (2002, 2003) also highlighted potential problems associated with the continuous disclosure as it applied to revisions of company profit forecasts in the immediate post-reform period. A number of factors constraining companies from

\footnotetext{
${ }^{9}$ An early Securities and Exchange Commission (SEC) study of the impact of Reg FD found that many investment professional believed that although the quantity of disclosures increased, the quality had deteriorated, with companies tending to issue more "boilerplate" press releases containing little useful in the way of information. See Unger (2001) for a discussion of this issue.

${ }^{10}$ Lee et al. (2006) argue, however, that stock idiosyncratic volatility comprises two components: (i) the noise component, and (ii) that part caused by information impacting on the fundamental value of the firm. More price information can decrease volatility by reducing the impact of noise traders. However more price information can increase stock volatility as the stock price more closely tracks the arrival of new information with respect to the fundamental value of the firm.

${ }^{11}$ This concern was voiced strongly by securities industry professionals in the US prior to the introduction of Reg FD. See Talosig (2004) for a summary of these arguments.
} 
providing timely revisions to profit forecasts were identified, including the reluctance of companies to disclose downward revisions until the last moment, either in the hope that a turnaround could be achieved or to avoid a negative reaction by investors; the difficulty companies faced in distinguishing between an aberration and a trend, and; the problems companies faced in preparing forecasts outside their normal six-monthly budget cycle.

Ultimately, the impact of the reforms on the earnings-related information environment is an empirical question. Before moving to a discussion of the empirical methods and data we briefly review relevant prior research.

\section{LITERATURE REVIEW}

In this section we review the empirical evidence on the enhanced disclosure (ED) reform introduced in Australia in 1994 and the Regulation Fair Disclosure (Reg FD) reform introduced in the US in 2000. The ED reform in Australia places a continuous disclosure obligation on ASX-listed companies and provided statutory backing for this obligation. On the other hand Reg FD in the US prohibits private communications between listed companies and securities market professionals such as analysts.

In respect of analysts' forecasts, Brown et al. (1999) found that forecasts became more accurate and less dispersed in the post-reform ED period. However, after controlling for other determinants of analysts' forecasts, they found no evidence of an improvement in analysts' forecast performance in the post-reform period. In the case of Reg FD, researchers report mixed results. Heflin et al. (2003) found that analysts' forecast became less accurate and more dispersed in the post-reform period. Again, 
however, their multivariate analysis found no evidence that changes in forecast errors or dispersion were related to the implementation of Reg FD. The univariate analysis of Bailey et al. (2003) found that analysts' forecast dispersion increased in the postreform period. Similarly, Irani et al. (2003) found that dispersion in analysts' forecasts increased in the post-reform period in both their univariate and multivariate analyses.

The evidence concerning the informational efficiency of stock prices is more consistent with predictions. Brown et al. (1999) found evidence that stock prices better anticipated the information content of listed companies' annual earnings

announcements in the post-reform period, indicating that the ED reform improved informational efficiency. The results were found, however, to be weak for large companies, suggesting that the reform had its greatest impact on the information environment for smaller companies. Heflin et al. (2003) found that deviations between pre- and post-announcement stock prices became smaller in the post-Reg FD period, indicating an improved informational efficiency of stock prices prior to earnings announcements in the post-reform period. Their multivariate analysis confirmed these findings.

\section{METHODOLOGY}

\subsection{Analysts' Forecasts}

We use two measures as proxies for analysts' earnings forecast performance: forecast error and dispersion. Forecast error $\left(\mathrm{FE}_{i t}\right)$ for firm $i$ at time $t$ is measured as (Brown et al., 1987; Lang et al., 1996; Kwon, 2002):

$$
F E_{i t}=\frac{\left|A E P S_{i t}-F E P S_{i t}\right|}{P_{i t}}
$$


where AEPS $_{\text {it }}$ is the actual earnings per share for firm $i$ at time $t$, FEPS $_{\text {it }}$ is the mean financial analysts' earnings forecast as of the date of the most recently updated forecast prior to the announcement for firm $i$ at time $t$ and $\mathrm{P}_{\mathrm{it}}$ is the stock price at the end of the firm's fiscal year $t$ for firm $i$.

We construct forecast dispersion $\left(\mathrm{FD}_{i t}\right)$ for firm $i$ at time $t$ as follows (Heflin et al., 2003):

$F D_{i t}=\frac{S D_{i t}}{P_{i t}}$

where $\mathrm{SD}_{\mathrm{it}}$ is the standard deviation of individual analysts' forecasts as of the date of the last forecast of annual earnings prior to the earning's announcement for firm $i$ at time $t$ and $\mathrm{P}_{\mathrm{it}}$ is the stock price at the end of the firm's fiscal year $t$ for firm $i$.

Since our objective is to examine changes in the information environment near the date of the earnings announcement, $\mathrm{FE}_{\mathrm{i}}$ and $\mathrm{FD}_{\mathrm{i}}$ are both measured on the date of the most recently updated forecast prior to the annual earnings announcements. Both $\mathrm{FE}_{\mathrm{i}}$ and $\mathrm{FD}_{\mathrm{i}}$ are scaled by the share price of the firm at the end of the fiscal year. Since computing forecast dispersion requires that at least two analysts issue the earnings forecasts, the analyses of forecast dispersion comprise fewer observations than the analyses of forecast errors.

As a first step we compare measures from the pre- and post-reform periods. Since the Act took effect on 1 December 2002, we define the pre-reform period to be between 1 January 2001 and 31 December 2002, and the post-reform period to be between 1 January 2003 and 31 December 2004. If the reform provides more timely disclosures, average analysts' forecast performance should improve as all analysts have the same 
information set and price-sensitive information is disclosed earlier. Thus, both forecast error and forecast dispersion should decline in the post-reform period. However, if as critics argue, the new regime impairs analysts' forecast performance, both measures should increase after the implementation of the reform.

To control for other factors that may affect analyst' forecast errors and forecast dispersion we also estimate the following pooled cross-sectional and time-series models where $\mathrm{t}=$ years 2000 to 2004 :

$$
\begin{gathered}
F E_{i t}=\alpha_{0}+\lambda_{1} R E F O R M+\lambda_{2} M V_{i t}+\lambda_{3} D A Y S_{i t}+\lambda_{4} A N A_{i t}+\lambda_{5} E S U P_{i t} \\
+\lambda_{6} N E G E_{i t}+\lambda_{7} L_{\text {OSS }}+\lambda_{8} F D_{i t}+e_{i t} \\
F D_{i t}=\alpha_{0}+\lambda_{1} R E F O R M+\lambda_{2} M V_{i t}+\lambda_{3} D A Y S_{i t}+\lambda_{4} A N A_{i t}+\lambda_{5} E_{S U P} \\
+\lambda_{6} N E G E_{i t}+\lambda_{7} L_{\text {OSS }}+e_{i t}
\end{gathered}
$$

where $\mathrm{FE}_{\mathrm{it}}$ and $\mathrm{FD}_{\mathrm{it}}$ are as defined in equations (1) and (2) respectively. REFORM is a dummy variable, which equals 1 if the observation is from the post-reform period, and 0 otherwise.

The other dependent variables are as follows (for convenience we abstract from the subscript time $\mathrm{t}=$ years 2000 to 2004). We include $\mathrm{MV}_{\mathrm{i}}$, the natural $\log$ of total market capitalization at the beginning of the fiscal year for firm $i$ to control for size since prior research finds that analysts' forecast performance improves with firm size (Brown et al., 1999; Lang et al., 1996; Mensah et al., 2004). We expect $\mathrm{MV}_{\mathrm{i}}$ to be negatively associated with $\mathrm{FE}_{\mathrm{i}}$ and $\mathrm{FD}_{\mathrm{i}}$. Furthermore, since later forecasts are more accurate than earlier forecasts prior to earnings announcements (Brown et al., 1999; Heflin et al., 2003; Kross et al., 1990), we include DAYS $\mathrm{S}_{\mathrm{i}}$, which is the natural log of the number of days by which the forecast precedes the earnings announcement for firm $i$, as a control for forecast horizon. We predict a positive relationship between 
DAYS and analysts' forecast performance. We include the number of analysts generating mean forecasts of earnings for firm $i\left(\mathrm{ANA}_{\mathrm{i}}\right)$ to capture analysts' following because firms with more analysts' following have smaller analysts' forecast errors and forecast dispersion (Brown et al., 1999; Kwon, 2002).

We also include as control variables several earnings characteristics of the firm that may have an impact on analysts' forecasting ability. We control for earnings variability by including earnings surprise $\left(\mathrm{ESUP}_{\mathrm{i}}\right)$ since analysts encounter more difficulties forecasting earnings for firms with large changes in earnings (Heflin et al., 2003; Lang et al., 1996). ESUP ${ }_{i}$ is defined as the absolute value of the difference between the current year's earnings per share ("EPS") and last year's EPS at time t, divided by the share price at the beginning of the fiscal year for firm $i$.

Lastly, we include two indicator variables, negative earnings $\left(\mathrm{NEGE}_{\mathrm{i}}\right)$ and loss $\left(\mathrm{LOSS}_{\mathrm{i}}\right)$, to capture the transitory effect of declining earnings and negative profits since analysts' forecasts exhibit more errors and dispersion when they follow firms with declining or negative earnings (Heflin et al., 2003). NEGE $\mathrm{i}_{\mathrm{i}}$ takes the value of 1 if firm i's current year EPS is below last year's EPS, and 0 otherwise while LOSS $_{\mathrm{i}}$ equals 1 if firm i's reported profits are negative and 0 otherwise.

In the regression model of absolute forecast error (equation (3)), a control for analyst disagreement $\left(\mathrm{FD}_{\mathrm{i}}\right)$ is incorporated since analysts disagree more when there is greater uncertainty about future earnings. This implies that their consensus forecasts are likely to be less accurate (Brown et al., 1999).

The variable which interests us the most is REFORM. We expect the REFORM coefficient to be negative if the implementation of the new regime improves analysts' forecast accuracy as more price-sensitive information has been released earlier and 
prior to the actual profit announcement. If the REFORM coefficient is positive, however, the evidence would suggest consensus analysts' forecast performance was impaired by the reform since they could no longer rely on management's private earnings-related information.

\subsection{Informational Efficiency of Stock Prices}

To investigate the effect of the new disclosure regime on information flows to the stock markets, we analyze the degree to which pre-announcement stock prices assimilate earnings-related information. The absolute deviation between the price on any day prior to an earnings announcement and the full-information postannouncement price is a measure of the information gap with regards to the upcoming earnings announcement.

We use the event study methodology to assess the merits of the alternative explanations. In respect of information disclosure, the event-study methodology has been used to examine the impact of stock suspensions invoked to improve the informational efficiency of stock prices (Kryzanowski, 1978; Kryzanowski, 1979; Howe et al., 1986) and to examine fraud-on-the-market litigation cases (Steen, 1994).

The traditional single-factor market model used in multiple event studies is often unsuitable for estimating expected returns and the measurement of abnormal returns when stocks do not trade each day.

To control for any thin trading bias in respect of small stocks in the sample a "tradeto-trade" approach using multi-period event returns is applied. Under the trade-to- 
trade returns approach the observed multi-period return ending on day $t$ is (see Maynes et al., 1993): ${ }^{12}$

$$
R_{i, n_{t}}=\ln \left[\frac{P_{i, t}}{P_{i, t-n_{t}}}\right]=\ln \left[\frac{P_{i, t}}{\hat{P}_{i, t-1}} \frac{\hat{P}_{i, t-1}}{\hat{P}_{i, t-2}} \cdots \frac{\hat{P}_{i, t-n_{t+1}}}{P_{i, t-n_{t}}}\right]
$$

where $R_{i, n_{t}}$ is return to firm $i$ over $n_{t}$ days, $P_{i, t}$ is the observed price for firm $i$ on day $t, \hat{P}_{i, t-s}$ is the unobserved price for firm $i$ on day $t$ - s (i.e., on a day the stock does not trade), $n_{t}$ is the length of the return interval ending on day $t$ (i.e., the number of days between observed or traded prices) and $\ln$ indicates that natural logarithms are used.

The single factor market model becomes:

$$
R_{i, n_{t}}=\alpha_{i} n_{t}+\beta_{i} R_{m, n_{t}}+\sum_{s=0}^{n_{t-1}} \varepsilon_{i, t-s}
$$

where $R_{m, n_{t}}$ is the return on the market index over $n_{t}$ days (where $n_{t}$ days matches the number of days between the observed or traded prices for firm $i$ ), $\beta_{i}$ is the parameter estimate for firm $i$ taken from ordinary least squares estimates, $\alpha_{i}$ is the intercept term for firm $i$ taken from ordinary least squares estimates and $\varepsilon_{i t}$ is the error term.

The error term in equation (6) will by heteroscedastic with variance equal to $n_{t} \sigma_{i}^{2}$ (assuming the variance of residuals is proportional to the length of the period between

\footnotetext{
${ }^{12}$ Under an event simulation study Maynes et al. (1993) report that using a methodology based on trade-to-trade returns is much better specified for all trading frequencies than returns forecast using a 'lumped' or 'uniform' treatment of missing trades. The lumped returns procedure assumes the stock return over non-trading days to be zero and assigns all the multi-period return to the day the stock actually trades. The uniform procedure allocates the return equally over all days in a multi-period interval where the stock does not trade.
} 
trades). To estimate the $\alpha$ and $\beta$ parameters in equation (6), a weighting scheme must be introduced whereby the return data are divided by the square root of $n_{t}$. The parameters $\alpha$ and $\beta$ are estimated by equation (7) below:

$$
\frac{R_{i, n_{t}}}{\sqrt{n_{t}}}=\alpha_{i} \sqrt{n_{t}}+\frac{\beta_{i} R_{m, n_{t}}}{\sqrt{n_{t}}}+\mu_{i, t}
$$

This correction (equation (7)) ensures that $\operatorname{var}\left(\mu_{j t}\right)$ is independent of $n_{t}$. We use a period of 180 trading days prior to the event window period (days $[-10,+10]$ ) to estimate the market model parameters in equation (7).

The abnormal return for firm $i$ over the event period is calculated as:

$$
A R_{i, n_{t}}=R_{i, n_{t}}-E\left[R_{i, n_{t}}\right\rfloor
$$

where $A R_{i, n_{t}}$ is the abnormal return for firm $i$ over the period $n_{t}$ days and $E\left[R_{i, n_{t}}\right\rfloor$ is the expected return for firm $i$ over the period $n_{t}$ days using the $\alpha$ and $\beta$ parameter estimates from equation (7).

Standard event study parametric statistical tests are used to detect evidence of abnormal returns (see Patell, 1976; Maynes et al., 1993).

Since our objective is to examine changes in the information environment around the date of the earnings announcement, we compute the absolute cumulative abnormal return $(\mathrm{ACAR})$ for each stock over the event window period days $[-10,+10]$, where day 0 is the fiscal year end earnings announcement date of the firm. The ACAR for firm $i$ on each of $t$ trading days around the annual earnings announcement is measured as: 


$$
A C A R_{i, t}=\left|\sum_{t=-x}^{t=+y} A R_{i t}\right|
$$

where $\mathrm{AR}_{\mathrm{it}}$ is the abnormal return for firm $i$ on day $t . t=-x$ is defined as the number of days the accumulation window extends backward from the earnings announcement date (day zero) for each year 2000 to 2004, and $t=+y$ is defined as the number of days the accumulation window extends forward from the earnings announcement date for each year 2000 to 2004 .

Thus, $\mathrm{ACAR}_{\mathrm{i}, \mathrm{t}}$ measures the absolute percentage change in price, after abstracting from market-wide movements, from $t$ equal to $x$ days before to $y$ days after the annual earnings announcement. It also measures the extent to which the information about the upcoming announcement is not reflected in the stock price starting $x$ days prior to the announcement (i.e., the information gap). A higher $\mathrm{ACAR}_{\mathrm{i}, \mathrm{t}}$ implies a larger information gap while a lower $\mathrm{ACAR}_{\mathrm{i}, \mathrm{t}}$ indicates a smaller information gap and higher informational efficiency of stock prices (Heflin et al., 2003).

Since the reform requires listed companies to disclose information in a more timely fashion, the market should move the price earlier and faster to its full information post-announcement level. This should be reflected in lower ACARs in the post-reform period compared to the pre-reform period. However, if investors react immediately based on the information without filtering it or considering other factors, the reform might result in larger price shocks and higher price volatility. If this is the case, higher ACARs may be observed in the post-reform period compared to the pre-reform period.

We also use a regression model to control for any changes in ACAR resulting from factors unrelated to the reform. Our sample selection procedure ensures each pre- and 
post-reform fiscal year contains the same firms, largely controlling for stationary firm-specific factors. We therefore focus primarily on controlling for those factors that are likely to have changed between the pre- and post-reform periods but unrelated to the reform. Accordingly, we estimate the following pooled cross-sectional and time-series regression for $t=$ years 2000 to 2004 .

$\mathrm{ACAR}_{i, t}=\alpha_{0, x}+\lambda_{1} \mathrm{REFORM}+\lambda_{2} \mathrm{MB}_{i t}+\lambda_{3} \mathrm{LEV}_{i t}+\lambda_{4} \mathrm{MV}_{i t}+\lambda_{5} \mathrm{ESUP}_{i t}+\lambda_{6} \mathrm{LOSS}_{i t}$ $+\lambda_{7} \mathrm{NEGCAR}_{i t}+\mathrm{e}_{i, t}$

Our main variable of interest is REFORM, which takes the value of 1 if the earnings announcement is from the post-reform period, and 0 otherwise. We expect the REFORM coefficient to be negative if earnings-related information availability improved in the post-reform period.

We include the ratio of market to book value of equity at the beginning of the fiscal year for firm $i\left(\mathrm{MB}_{\mathrm{i}}\right)$ to control for growth opportunities. ${ }^{13}$ High growth firms have greater information asymmetry between insiders and investors and we expect $M B_{i}$ to be positively related to ACARs (e.g., Collins et al., 1989; Gaver et al., 1993). The ratio of total liabilities to total assets for firm $i\left(\mathrm{LEV}_{\mathrm{i}}\right)$ captures default risk of debt and is expected to yield a positive relationship with the ACARs (e.g. Dhaliwal et al., 1991).

We include the natural log of total market capitalization at the beginning of the fiscal year for firm $i\left(\mathrm{MV}_{\mathrm{i}}\right)$ to control for firm size, as evidence suggests that stock prices of large firms reflect the information content of reported earnings earlier and faster than small firms (e.g., Atiase, 1985; Freeman, 1987; Ro, 1988).

\footnotetext{
${ }^{13}$ Again for convenience we abstract from the subscript time $\mathrm{t}=$ years 2000 to 2004 .
} 
Finally, following Holthausen et al. (1988), we include a set of variables to control for information-related factors unrelated to the reform. ESUP, LOSS $_{\mathrm{i}}$ and NEGCAR $\mathrm{ire}$ included in this category of controls. ESUP $\mathrm{i}_{\mathrm{i}}$ equals the absolute value of the difference between the current EPS and last year's EPS at time t, divided by the share price at the beginning of the fiscal year for firm $i$. We expect a bigger EUSP to be associated with a larger ACAR in response to the earnings announcement. LOSS $_{\mathrm{i}}$ takes the value of 1 if a firm's reported profits are negative, and 0 otherwise to capture pre-announcement information and the differences in the accuracy of the earnings signal (e.g., Francis et al., 1996; Hayn, 1995). We expect losses to impair the market's ability to forecast the upcoming earnings numbers. NEGCAR $\mathrm{N}_{\mathrm{i}}$ equals 1 if the cumulative abnormal return is negative over the event window period $[-10,+3]$, and 0 otherwise. The variable captures inherent price variability since greater price movements are more likely to occur when prices decrease compared to when prices increase (e.g., Christie, 1982). We expect both $\mathrm{LOSS}_{\mathrm{i}}$ and NEGCAR $\mathrm{i}$ to be positively related to the firm's ACAR (e.g., Christie, 1982; Hayn, 1995; Heflin et al., 2003).

\section{DATA}

\subsection{Sample Period}

We examine the effect of the reform by analyzing changes in various proxies for the firms' financial information environment prior to the annual earnings announcements during a two-year period before and after the introduction of the new regime. As noted earlier, since the Act took effect in December 2002, we define the pre-reform period to be 1 January 2001 - 31 December 2002, and the post-reform period to be 1 January 2003 - 31 December 2004. 


\subsection{Sample Selection and Data Collection}

To be included in our sample a NZX-listed company must be continuously listed for the four-year sample period. Actual and forecast annual EPS data are collected from International Brokers Estimate System (I/B/E/S). I/B/E/S covers only 83 NZX-listed companies in total. We eliminate 43 stocks where $\mathrm{I} / \mathrm{B} / \mathrm{E} / \mathrm{S}$ does not have the required data for all four years of the sample period or there is an incomplete data set for the control variables. Our final sample for the analysis of analysts' forecasts consisted of 40 NZX-listed stocks.

We obtained data on the market index, adjusted stock returns and a non-trading flag from the NZX for New Zealand firms that were continually listed for the entire four year period between 2000 and 2004. The sample for the analysis of stock price information efficiency comprises 62 NZX-listed stocks. Data for the control variables and earnings announcement dates were all sourced from Datex.

\section{EMPIRICAL RESULTS}

\subsection{Analysts' Forecasts}

\subsubsection{Univariate Tests}

Table 1 provides a comparison of the mean and median analysts' forecast errors and forecast dispersion during the pre-reform and post-reform periods. The results for the forecast error are mixed and offer little support for H1. The median absolute forecast error decreased from 0.0092 in the pre-reform period to 0.0060 in the post-reform period consistent with hypothesis H1. However this difference is not significant at the 0.05 level. In contrast, the mean absolute forecast error increased from 0.0253 in the 
pre-reform period to 0.0429 in the post-reform period (but again the difference was not statistically significant).

The results for forecast dispersion are more uniform. The mean (median) forecast dispersion decreased from $0.0118(0.0063)$ in the pre-reform period to 0.0072 $(0.0043)$ in the post-reform period. These differences are statistically significant at the 0.05 level. These results suggest that analysts' forecasts showed greater convergence in the post-reform period. The result is consistent with $\mathrm{H} 1$ suggesting that in the postreform period the same information set was available to all analysts.

INSERT TABLE 1 HERE

\subsubsection{Multivariate Analysis}

Panel A of Table 2 reports descriptive statistics on the control variables for the full sample period and separately for the pre-reform and post-reform periods. The pvalues show that in the post-reform period, only the decline in the median ESUP and mean and median NEGE are significant at the 0.10 level. This suggests, weakly, that earnings exhibited more time-series variability, and were more often higher than previous earnings in the post-reform period.

\section{INSERT TABLE 2 HERE}

Panel B of Table 2 shows the Pearson correlations between dependent variables (i.e., FE and FD), the REFORM dummy variable and the control variables. The data show that FE has a positive and significant relationship (at the 0.01 level) with FD, ESUP and LOSS, indicating that mean analysts' forecast error is greater the higher the dispersion of analysts' forecasts, or when earnings have more time-series variability or for firms that report a loss. 
FD is significantly correlated at the 0.1 level or greater with all control variables except for DAYS and NEGE. Like FE, FD is positively correlated with ESUP and LOSS, suggesting analysts' forecasts are more dispersed when they follow firms with more time-series variability in earnings and with negative reported profits. FD is significantly negatively correlated with MV and ANA, which implies that large firms and firms with greater analyst following have less analysts' forecast dispersion. Most importantly, FD is negatively correlated with REFORM and the correlation is statistically significant at the 0.01 level, suggesting that analysts' forecasts become less diverse in the post-reform period.

It is noticeable that among the control variables, MV and ANA are highly correlated with a correlation co-efficient of 0.6630 , statistically significant at the 0.01 level. It is likely that analysts have incentives to focus on large firms because they are more widely held, attract more interest from a broader set of investors and generate greater commissions for brokerage firms. ${ }^{14}$ To control for interdependence among these firm specific variables, we include either MV or ANA (but not both) in the regression models.

Table 3 presents estimation results from OLS and fixed effects regression models with FE as the dependent variable. ${ }^{15}$ If analysts' forecast accuracy is improved by the

\footnotetext{
${ }^{14}$ There is a large literature on the determinants of analysts following. Arbel et al. (1983) document that since financial analysts' primary customers are institutional investors, they concentrate their activities on large firms. In a cross-sectional study, Bhushan (1989) investigates the key determinants of the number of analysts following and finds that the number of analysts following a firm is increasing in firm size. An alternative explanation for the large-firm focus of analysts is that large firms engage in more transactions and tend to be more diversified than small firms. Therefore, MV and ANA are positively and significantly correlated.

${ }^{15}$ In OLS regressions we employed the Belsley et al. (1980) approach and measure the condition index to detect for multicollinearity. The condition index is defined as the square root of the ratio of the
} 
reform, the sign of the coefficient on REFORM variable should be negative, consistent with H1. On the contrary, if the reform impaired analysts' forecasting ability, the coefficient on REFORM should be positive.

In models 1 and 2, the coefficient on REFORM is positive in both the OLS and fixed effects models but small in magnitude and not statistically significant at conventional levels. The forecast error is positively and significantly (at the 0.01 level) associated with ESUP, suggesting that analysts' forecasts are less accurate in cases where there are significant changes in earnings. A positive and significant coefficient on LOSS also indicates that analysts have more difficulty forecasting earnings for firms with negative reported profits, and their forecasts exhibit less accuracy. These findings are consistent with prior evidence (e.g., Heflin et al., 2003; Lang et al., 1996).

\section{INSERT TABLE 3 HERE}

Models 3 and 4 include the variable ANA in place of MV. The coefficient on REFORM in both the OLS and the fixed effects models are still positive but are again not significant. The coefficients on EUSP and LOSS are positive and significant at the 0.01 level. In both models 1 to 4 inclusive the coefficient estimates for DAYS is negative (contrary to expectations) and not consistent with previous research which documents a negative relationship between dispersion in analysts' forecasts and the forecast horizon (e.g., Heflin et al., 2003; Kross et al., 1990; Kwon, 2002).

\footnotetext{
largest eigenvalue to each individual eigenvalue. The condition indexes were between 10 and 20 and we found no evidence of strong multicollinearity as evidenced by condition index values in excess of 30 .
} 
Overall, our results show that after controlling for other factors there was no significant change in analysts' forecast errors in the post-reform period. These results do not support hypothesis H1.

The results from regression models with FD as the dependent variable are presented in Table 4. The coefficients on REFORM are negative and statistically significant at the 0.05 level or better in all regression models, except for the fixed effects regression model 2 (column 4 of Table 4). The results suggest that analysts' forecast dispersion decreased in the post-reform period, consistent with hypothesis H1.

In all regressions (both OLS and fixed effects models) the coefficients on the control variable LOSS was positive and significant at the 0.10 level or better, suggesting analysts disagree more about forecast earnings for firms with negative reported profits. In addition, the negative and significant coefficient on MV (models 1 and 2) suggests that analysts' forecasts are more disperse for smaller firms. The negative and significant relationship between ANA and FD in the OLS regression model 3 is also consistent with prior studies which have found that firms with more analysts following have less forecast disagreement (e.g., Kwon, 2002).

\section{INSERT TABLE 4 HERE}

Overall our finding that the reform is associated with a significant decline in analysts' dispersion of earnings forecasts is consistent with hypothesis H1. In this respect our results differ from those reported by Brown et al. (1999) and Heflin et al. (2003) who found that neither forecast error nor forecast dispersion were affected by the reforms 
that took place in the Australian and US markets respectively after controlling for other factors. ${ }^{16}$

\subsection{Informational Efficiency of Stock Price}

\subsubsection{Univariate Tests}

Figure 1 plots the mean and median ACARs commencing ten trading days before to ten trading days after the firm's earnings announcements for both the pre- and postreform period. Panel A of Figure 1 shows that the mean post-reform ACARs are always smaller than the mean pre-reform ACARs in the 20 trading days surrounding the announcement day. The distance between the pre- and post-reform ACARs is relatively constant until day -2 , when the gap widens over the period $[-2,+3]$ and stays relatively constant thereafter. Panel A of Figure 1 suggests that the information gap, as reflected in the deviation between the pre-announcement price and the full information post-announcement price, is smaller in the post-reform period, indicating that the reform is associated with superior pre-announcement information and greater stock price efficiency.

\section{INSERT FIGURE 1 HERE}

Panel B of Figure 1 provides the results for the median ACARs. In respect of the median ACARS there is no striking difference between the pre and post-reform ACARS up to day [-1]. Over the days $[0,+3]$ the median ACARs in the post-reform period drops below the median ACAR in the pre-reform period but the gap narrows again by day +8 .

\footnotetext{
${ }^{16}$ The univariate tests of Brown et al. (1999) and Heflin et al. (2003) did, however, find weak evidence of an increase in analysts' forecast errors and dispersion following the disclosure reform.
} 
Table 5 presents statistical tests of the differences between the pre- and post-reform pooled cross-sectional mean and median ACARs for five different accumulation event day window periods: $[-2,+3],[-2,+4],[-3,+3],[-3,+4]$ and $[-10,+3]$, where day 0 is the earnings announcement day. Day +3 is that day in the event window period that all stocks in the sample traded at least once subsequent to the announcement day 0 . The post-reform mean and median ACARs are lower than the mean and median prereform ACARs for all five window periods. The differences in the mean ACARs for the event windows $[-2,+3],[-2,+4]$ and $[-3,+3]$ between the pre- and post-reform periods are significant at the 0.05 level. This suggests that as the annual earnings announcement date approaches, pre-announcement post-reform prices move earlier to their full-information levels than pre-reform prices. This finding is consistent with hypothesis $\mathrm{H} 2$.

\section{INSERT TABLE 5 HERE}

In summary our univariate results provide some evidence that superior preannouncement information is available to market participants prior to earnings announcements after the enactment of the reform. Our univariate results are also consistent with the evidence of Heflin et al. (2003) and Brown et al. (1999) that share prices reflected more information regarding the upcoming earnings announcements and accounting data in the post-reform period.

\subsubsection{Regression Analysis}

Panel A of Table 6 displays descriptive statistics on the control variables in Equation (10) for the full sample period and the pre- and post-reform periods separately. The post-reform means and medians for the control variables are not significantly different from each other. 


\section{INSERT TABLE 6 HERE}

Panel B of Table 6 shows the Pearson correlation matrix for the REFORM indicator variable and the control variables. Although MB, LEV, LOSS and NEGCAR are all negatively related to REFORM, their correlations with REFORM are small in magnitude and not significant at conventional levels. REFORM has a positive correlation with MV and EUSP but again none of the correlations are significant.

Among the control variables, MB is significantly and positively correlated with LEV suggesting more highly levered firms have a higher market-to-book ratio. MV is also significantly and positively correlated with MB and LEV, indicating that large firms are more likely to have a higher market-to-book ratio and higher leverage. The negative correlations between MV and EUSP, and MV and LOSS (significant at the 0.01 level) suggest large firms are more likely to report a decrease in profit. LOSS is also positively correlated with LEV and EUSP suggesting more highly levered companies and firms that have a large earnings surprise are more likely to report a loss.

Table 7 presents the results from the OLS and fixed effects regression models over each of the five accumulation windows. ${ }^{17}$ The REFORM coefficient is negative for all five accumulation windows and significant at the 0.10 level or better in all event window periods other than the period $[-10,+3]$. The results suggest that the deviation between the pre-announcement price and the full information post-announcement price declines in the post-reform period and that the market responds to information

\footnotetext{
${ }^{17}$ In OLS regressions in Tables 7 and 8 we again calculated the condition index to detect for multicollinearity. Similar to our results in Tables 3 and 4 we found no evidence of any strong multicollinearity that may impact on our regression results.
} 
about the upcoming annual earnings announcement earlier. That is, the pre-earnings announcement price is closer to its post-earnings announcement level earlier after the implementation of the reform compared to the pre-earnings announcement price prereform. Again, this result is consistent with hypothesis $\mathrm{H} 2$.

\section{INSERT TABLE 7 HERE}

The results for control variables are mixed. The positive coefficients on LEV and LOSS (except for the fixed effect model in the period $[-3,+5]$ ) are consistent with previous studies (e.g., Dhaliwal et al., 1991; Hayn, 1995; Heflin et al., 2003), suggesting that firms with higher leverage and negative reported profits are more likely to have a higher information gap prior to their earnings announcement dates. Contrary to expectations the coefficients on MB are negative and significant at the 0.10 level for the event window periods $[-2,+3]$ and $[-3,+3]$ for the OLS models. The coefficient on MV is negative and statistically significant at the 0.10 and 0.05 levels for the OLS regression models in the event window periods $[-2,+3]$ and $[-2,+4]$ respectively. This suggests that investors in large firms anticipate information arrival earlier than those in small firms and more quickly move stock prices closer to their full information post-announcement level. The finding of a negative coefficient on MV is consistent with the evidence in Atiase (1985) and Freeman (1987). The coefficients on EUSP are generally positive across all models and significant at the 0.10 level in the OLS models for event window periods $[-2,+4],[-3,+3]$ and $[-3,+5]$, suggesting that a greater earnings surprise is associated with a more significant price reaction to the announcement.

The coefficients on NEGCAR are positive and significant at the 0.05 level in the event window period $[-2,+3]$ (both the OLS and fixed effects models) and in the event 
window periods $[-2,+4]$ and $[-3,+3]$ (fixed effects models only). This supports the results reported in recent literature (Heflin et al., 2003) that firms that announce losses or have a negative abnormal return in the pre-announcement period experience a larger price reaction to the earnings announcement.

In Table 8 we repeat the regression analysis undertaken in Table 7 for the event window periods $[-2,+3]$ and $[-2,+4]$, except we divide the sample evenly into small and large firms based on the market capitalisation of the firm in the 2001 fiscal yearend. The results in Table 8 show that for small firms the coefficient on REFORM is negative and significant at the 0.10 level or better for both event window periods under the OLS and fixed effects regression models. In contrast for large firms the coefficient on REFORM is positive but not significant. This suggests that the empirical support for $\mathrm{H} 2$ is driven by small firms. This may reflect greater analyst coverage for larger firms and more disclosures by large firms in both pre-reform and post-reform (e.g. Arbel et al., 1983; Bhushan, 1989). ${ }^{18}$

\section{INSERT TABLE 8 HERE}

For small firms the coefficient on EUSP is positive and significant at the 0.10 level in the fixed effects regression model for both event window periods $[-2,+3]$ and $[-2,+4]$. For small firms the coefficient on NEGCAR is also positive and significant at the 0.05 and 0.10 level in the fixed effect model respectively over the event window periods [$2,+3]$ and $[-2,+4]$.

\footnotetext{
${ }^{18}$ The very large firms stocks that are dual listed on the Australian Stock Exchange would be already subject to a continuous disclosure regime similar to that introduced into New Zealand.
} 


\section{SUMMARY AND CONCLUSIONS}

In this study we examine the impact of the introduction of an enhanced continuous disclosure regime in December 2002 on the information environment for NZX-listed stocks. The aim of the reforms was to enhance investor confidence in the New Zealand equity market by requiring companies to immediately disclose all pricesensitive information rather than having information being treated as an asset of the firm. The new continuous disclosure rules of the NZX also received statutory backing. We hypothesise that the requirement for more timely disclosure of price-sensitive information will improve analysts' forecast performance and move stock prices closer to their full-information price level.

Our univariate analysis finds that the reforms had a beneficial impact on both analysts' forecast error and forecast dispersion. After controlling for other factors, we found there was a significant improvement in analysts' forecast dispersion, but not in forecast error, in the post-reform period, providing partial support for our first hypothesis. Nonetheless, our results are broadly consistent with the intent of the reform and the results of studies examining the impact of either the ED reform of 1994 in Australia (Brown et al., 1999) and the Reg FD reform of 2000 enacted in the US (e.g., Heflin et al., 2003; Bailey et al., 2003; Irani et al., 2003).

Our results vis-a-vis those reported by Brown et al. (1999) are also significant since the changes introduced in New Zealand were arguably less dramatic than those introduced by the ED reform in Australia in $1994 .{ }^{19}$ Our results suggest that the reforms were associated with an improvement in the flow of information to investors rather than with a disruption in the information flow feared by critics of the reform. 
In respect of informational efficiency, our univariate analyses show that the ACARs around the earnings announcement date event window periods are generally lower in the post-reform period, consistent with a smaller information gap after the implementation of the reform. This result holds after controlling for other factors. Our regression results also suggest that the impact of the reform with respect to price efficiency was greatest for small firms. These findings are consistent with our second hypothesis and with the results of prior research examining the impact of both the ED reform in Australia (e.g., Brown et al., 1999) and the Reg FD reform in the US (e.g., Heflin et al., 2003). Again, these results suggest that concerns over the reform disrupting the price formation process were unwarranted.

While some caution is needed in the interpretation of our results, we find that the disclosure reform of 2002 had a beneficial impact on the information environment for NZX-listed stocks, consistent with the intent of the reforms. Our findings are stronger than the results of prior research examining the impact of a similar reform in Australia (e.g. Brown et al., 1999). In addition our results offer evidence contrary to the proposition that successful prosecution of violations of securities markets regulations rather than the introduction of sanctions is essential to changing firm and market behaviour (e.g., Bhattacharya et al., 2002).

\footnotetext{
${ }^{19}$ For example, see Pankhurst (2002)
} 


\section{References}

Abarbanell, J. S., W. N. Lanen, and R. E. Verrecchia (1995), Analysts' forecasts as proxies for investor beliefs in empirical research, Journal of Accounting and Economics, Vol. 20, No. 1, pp. 31-60.

Arbel, A., S. Carvell, and P. Strebel (1983), Giraffes, institutions and neglected firms, Financial Analysts Journal, Vol. 39, No. 3, pp. 57-63.

Atiase, R. K., (1985), Predisclosure information, firm capitalization, and security price behavior around earnings announcements, Journal of Accounting Research, Vol. 23, No. 1, pp. 21-36.

Bailey, W., H. Li, C. X. Mao, and R. Zhong, (2003), Regulation Fair Disclosure and earnings information: market, analyst, and corporate responses, Journal of Finance, Vol. 58, No. 6, pp. 2487-2514.

Ball, R., and P. Brown, (1968)), An empirical evaluation of accounting income numbers, Journal of Accounting Research, Vol. 6, No. 2, pp. 159-178.

Beaver, W. H., (1968), The information content of annual earnings announcements, Journal of Accounting Research, Vol. 6, pp. 67-92.

Belsley, D. A., E. Kuh and R. E. Welsch, (1980), Regression Diagnostics, New York: John Wiley and Sons Inc.

Bhattacharya, U. and H. Daouk, (2002), The world price of insider trading, Journal of Finance, Vol. 57, No. 1, pp. 75-108.

Bhushan, R., (1989), Firm characteristics and analyst following, Journal of Accounting and Economics, Vol. 11, No. 2\&3, pp. 255-274.

Brown, L. D., R. L. Hagerman, P. A. Griffin and M. E. Zmijewski, (1987), Security analyst superiority relative to univariate time-series models in forecasting quarterly earnings, Journal of Accounting and Economics, Vol. 9, No. 1, pp. 61-87.

Brown, P., S. L Taylor, and T. S. Walter, (1999), The impact of statutory sanctions on the level and information content of voluntary corporate disclosure, Abacus, Vol. 35, No. 2, pp. 138-162.

Christie, A. A., (1982), The stochastic behavior of common stock variances: Value, leverage and interest rate effects, Journal of Financial Economics, Vol. 10, No. 4, pp. 407-432.

Collins, D. W., and S. P. Kothari, (1989), An analysis of intertemporal and crosssectional determinants of earnings response coefficients, Journal of Accounting \& Economics, Vol. 11, No. 2\&3, pp. 143-181.

Dalziel, L., (2002), Securities bill builds confidence, New Zealand Herald, December 3.

Dhaliwal, D. S., K. J. Lee, and N. L. Fargher, (1991), The association between unexpected earnings and abnormal security returns in the presence of financial leverage, Contemporary Accounting Research, Vol. 8, No. 1, pp. 20-41.

Dubow, B. and N. Monterio, (2006), Measuring market cleanliness, Financial Services Authority, Occasional paper series 23. 
Dunstan, K., G. Gallery and T. Troung, (2005), The impact of New Zealand's statutory-backed continuous disclosure regime on corporate disclosure behaviour, working paper, Victoria University of Wellington.

, (2006), The impact of the statutory-backed continuous regime on the market reaction to management earnings forecasts and earnings announcements in New Zealand, working paper, Victoria University of Wellington.

Francis, J., J. D. Hanna and L. Vincent, (1996), Causes and effects of discretionary asset write-offs, Journal of Accounting Research, Vol. 34, pp. 117-134.

Franks, S., (2002), Govt favours obtuse over obvious, New Zealand Herald, June 11.

Freeman, R. N., (1987), The association between accounting earnings and security returns for large and small firms, Journal of Accounting and Economics, Vol. 9, No. 2, pp. 195-228.

Frijns, B., A. Gilbert and A. Tourani-Rad, (2006), Insider trading, regulation and the components of the bid-ask spread, working paper, Auckland University of Technology.

Gaver, J. and K. Gaver, (1993), Additional evidence on the association between the investment opportunity set and corporate financing, dividend and compensation policy. Journal of Accounting and Economics, Vol. 16, No. 1-3, pp. 125-160.

Gaynor, B., (2002), Get ready for new disclosure rules, New Zealand Herald, November 16.

22.

, (2003), Warning signs disclose problems, New Zealand Herald, February

Hayn, Carla, (1995), The information content of losses, Journal of Accounting and Economics, Vol. 20, No. 2, pp. 125-153.

Heflin, F., K. R. Subramanyam, and Y. Zhang, (2003), Regulation FD and the financial information environment: early evidence, Accounting Review, Vol. 78, No. 1, pp. 1-37.

Holthausen, R. W. and R. E. Verrecchia, (1988), The effect of sequential information release on the variance of price changes in an intertemporal multi-asset market, Journal of Accounting Research, Vol. 26, No. 1, pp. 82-106.

Howe, J.S. and G.G. Schlarbaum, (1986), SEC trading suspensions: empirical evidence, Journal of Financial and Quantitative Analysis, Vol. 21, No. 3, pp. 323333.

Irani, A. J. and I. Karamanou, (2003), Regulation Fair Disclosure, analyst following, and analyst forecast dispersion, Accounting Horizons, Vol. 17, No. 1, pp. 15-29.

Kim, O., (1993), Disagreements among shareholders over a firm's disclosure policy. Journal of Finance, Vol. 48, No. 2, pp. 747-760.

Kim, O. and R. E. Verrecchia, (1991), Market reaction to anticipated announcements, Journal of Financial Economics, Vol. 30, No. 2, pp. 273-309.

Kim, O. and R. E. Verrecchia, (1994), Market liquidity and volume around earnings announcements, Journal of Accounting and Economics, Vol. 17, No. 1\&2, pp. 41-67. 
Kross, W., B. Ro and D. Schroeder, (1990), Earnings expectations: the analysts' information advantage, Accounting Review, Vol. 65, No. 2, pp. 461-476.

Kryzanowski, L., (1978), Misinformation and regulatory actions in the Canadian capital markets; some empirical evidence, Bell Journal of Economics, Vol. 9, No. 2, pp. 335-368.

, (1979), The efficacy of trading suspensions: a regulatory action designed to prevent the exploitation of monopoly information, Journal of Finance, Vol. 34, No. 5, pp. 1187-1200.

Kwon, S. S., (2002), Financial analysts' forecast accuracy and dispersion: high-tech versus low-tech stocks, Review of Quantitative Finance and Accounting, Vol. 19, No. 1, pp. 65-91.

Lang, M. H., and R. J. Lundholm, (1996), Corporate disclosure policy and analyst behavior, Accounting Review, Vol. 71, No. 4, pp. 467-492.

Lee, D. and M. Liu, (2006), Does more information in stock price lead to greater or smaller idiosyncratic return volatility?, working paper, University of Kentucky.

Maynes, E. and J. Rumsey, (1993), Conducting event studies with thinly traded stocks, Journal of Banking and Finance, Vol. 17, No. 1, pp. 145-157.

Mensah, Y. M., X. Song, and S. S. M. Ho, (2004), The effect of conservation on analysts' annual earnings forecast accuracy and dispersion, Journal of Accounting, Auditing \& Finance, Vol. 19, No. 2, pp. 159-183.

New Zealand Exchange, (2002), Continuous Disclosure.

http://www.nzx.com/regulation/listed_issuer/Continuous_Disclosure.

New Zealand Exchange, (2005), Guidance Note - Continuous Disclosure. http://www.nzx.com/regulation

Pankhurst, P., (2002), Securities law shake-up, not an earthquake. New Zealand Herald, December 2.

Patell, J., (1976), Corporate forecasts of earnings per share and stock price behavior: Empirical tests, Journal of Accounting Research, Vol. 14, No. 2, pp. 246-276.

Poskitt, R. and P. Yang, (2005), The impact of disclosure reform on information risk in NXZ-listed stocks, forthcoming in Pacific Accounting Reveiw.

Ro, B. T., (1988), Firm size and the information content of annual earnings announcements, Contemporary Accounting Research, Vol. 4, No. 2, pp. 438-449.

Securities Commission, (2002), Strengthening confidence in New Zealand's capital markets, http://www.sec-com.govt.na/publications/documents/capital_markets.shtml.

Steen, C. H., (1994), The econometrics of fraud-on-the-market securities fraud, Journal of Legal Economics, Vol. 4, No. 1, pp. 11-45.

Talosig, P., (2004), Regulation FD - fairly disruptive? An increase in capital market inefficiency, Fordham Journal of Corporate and Financial Law, Vol. 9, No. 3, pp. 637-714.

The Financial Services Authority, (2000), UK Listing Authority: continuing obligations guide, http://www.fsa.gov.uk, May, pp. 1-41. 
Unger, L. S., (2001), Special Study; Regulation fair Disclosure revisited. Securities and Exchange Commission. http://www.wec.gov/news/studies/regfdstudy.htm

Wilkinson, B., (2003), Reform of securities trading law: evolution and risks, LexisNexis Conference: Securities Markets and Institutions. 
Table 1

Absolute Analyst Forecast Error and Forecast Dispersion

\begin{tabular}{lcccc}
\hline & \multicolumn{2}{c}{ Forecast error } & \multicolumn{2}{c}{ Forecast dispersion } \\
& $\mathbf{N = 1 6 0}$ & Mean & Median \\
& Mean & Median & 0.0118 & 0.0063 \\
Pre-reform & 0.0253 & 0.0092 & 0.0072 & 0.0043 \\
Post-reform & 0.0429 & 0.0060 & 0.0046 & 0.0020 \\
Difference & -0.0176 & 0.0032 & $(0.02)$ & $(0.01)$ \\
p-value & $(0.26)$ & $(0.27)$ & \\
\hline
\end{tabular}

Forecast error is the absolute value of the difference between actual earnings and the mean of the individual analyst forecasts scaled by the firm's share price at the end of the fiscal year. Forecast dispersion is the standard deviation of the individual analysts' forecasts scaled by the firm's share price at the end of fiscal year. $\mathrm{N}$ is the total number of observations. The pre-reform period is the period from 1 January 2001 to 31 December 2002, while the post-reform period is the period from 1 January 2003 to 31 December 2004. All p-values are two-sided. P-values for means are from t-tests of the difference between the pre- and post-reform means. For medians, p-values are from Mann Whitney U tests. 
Table 2

Panel A: Descriptive Statistics for Control Variables in the Regressions of Absolute Forecast Error and Forecast Dispersion

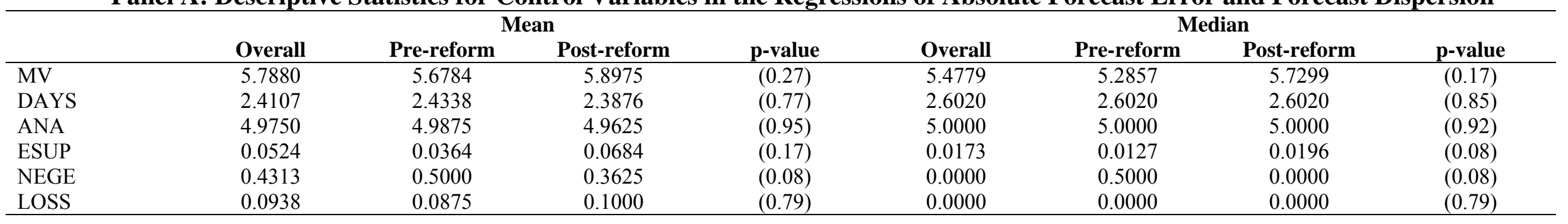

Panel B: Pearson Correlations among the Dependent Variables, REFORM Indicator and the Control Variables

\begin{tabular}{|c|c|c|c|c|c|c|c|c|}
\hline & FD & REFORM & MV & DAYS & ANA & ESUP & NEGE & LOSS \\
\hline $\mathrm{FE}$ & $0.3728 * *$ & 0.0892 & -0.0171 & -0.0022 & -0.1134 & $0.8913 * *$ & 0.1289 & $0.5799 * *$ \\
\hline FD & & $-0.1931 * *$ & $-0.2001 *$ & 0.1056 & $-0.2013 * *$ & $0.2940 * *$ & -0.1388 & $0.4248 * *$ \\
\hline REFORM & & & 0.0876 & -0.0233 & -0.0053 & 0.1089 & -0.1388 & 0.0214 \\
\hline MV & & & & 0.1321 & $0.6630^{* *}$ & 0.0166 & -0.0722 & 0.0495 \\
\hline DAYS & & & & & 0.1164 & -0.0102 & -0.0250 & 0.0989 \\
\hline ANA & & & & & & -0.1068 & 0.0253 & -0.0513 \\
\hline ESUP & & & & & & & 0.1035 & $0.4160 * *$ \\
\hline NEGE & & & & & & & & $0.1962 *$ \\
\hline
\end{tabular}

$\mathrm{FE}=$ the absolute value of the difference between actual earnings and the mean of the individual analyst forecasts scaled by the firm's share price at the end of the fiscal year; $\mathrm{FD}=$ the standard deviation of the individual analysts' forecast scaled by the firm's share price at the end of the fiscal year; REFORM $=1$ if the observation is from the postreform period, and 0 otherwise; MV = natural log of the firm's total market capitalization at the beginning of the fiscal year; DAYS = natural log of the average number of days by which the forecast precedes the earnings announcement; ANA = the number of analysts who generate a mean forecast of earnings; ESUP = the absolute value of the difference between the current year's EPS and last year's EPS, divided by the price at the beginning of the fiscal year; NEGE $=1$ if current earnings are below previous earnings, and 0 otherwise; LOSS $=1$ if reported profits are negative, and 0 otherwise. All p-values are two-sided. P-values for means are from t-tests of the difference between the pre- and post-reform means. For medians, p-values are from Mann Whitney $\mathrm{U}$ tests. $* *$ Correlation is significant at the 0.01 level $(2$-tailed). * Correlation is significant at the 0.05 level (2-tailed). 
Table 3

Regression of Absolute Analyst Forecast Error on REFORM Indicator and Control Variables $F E_{i t}=\alpha_{0}+\lambda_{1} R E F O R M+\lambda_{2} M V_{i t}+\lambda_{3} D A Y S_{i t}+\lambda_{4} A N A_{i t}+\lambda_{5} E S U P_{i t}+\lambda_{6} N E G E_{i t}+\lambda_{7} L O S S_{i t}+\lambda_{8} F D_{i t}+e_{i t}$

\begin{tabular}{|c|c|c|c|c|c|}
\hline & & Model 1 OLS & Model 2 Fixed effects & Model 3 OLS & Model 4 Fixed effects \\
\hline Variable & Predicted sign & Coefficient (t stats) & Coefficient (t stats) & Coefficient (t stats) & Coefficient (t stats) \\
\hline Constant & & $\begin{array}{l}0.0179 \\
(0.98)\end{array}$ & $\begin{array}{c}-0.0030 \\
(-0.03)\end{array}$ & $\begin{array}{c}0.0050 \\
(0.40)\end{array}$ & $\begin{array}{r}0.0027 \\
(0.08)\end{array}$ \\
\hline REFORM & -ve & $\begin{array}{l}0.0015 \\
(0.22)\end{array}$ & $\begin{array}{l}0.0022 \\
(0.26)\end{array}$ & $\begin{array}{l}0.0013 \\
(0.19)\end{array}$ & $\begin{array}{l}0.0025 \\
(0.32)\end{array}$ \\
\hline $\mathrm{MV}$ & -ve & $\begin{array}{l}-0.0028 \\
(-1.04) \\
\end{array}$ & $\begin{array}{l}0.0001 \\
(0.01) \\
\end{array}$ & & \\
\hline DAYS & $+\mathrm{ve}$ & $\begin{array}{l}-0.0021 \\
(-0.60)\end{array}$ & $\begin{array}{c}-0.0030 \\
(-0.63) \\
\end{array}$ & $\begin{array}{l}-0.0025 \\
(-0.71) \\
\end{array}$ & $\begin{array}{c}-0.0028 \\
(-0.60) \\
\end{array}$ \\
\hline ANA & -ve & & & $\begin{array}{c}-0.0006 \\
(-0.38)\end{array}$ & $\begin{array}{c}-0.0018 \\
(-0.51)\end{array}$ \\
\hline ESUP & $+\mathrm{ve}$ & $\begin{array}{c}0.5257 \\
(21.51)^{* * *}\end{array}$ & $\begin{array}{c}0.5022 \\
(15.38)^{* * *}\end{array}$ & $\begin{array}{c}0.5241 \\
(21.35)^{* * *}\end{array}$ & $\begin{array}{c}0.4988 \\
(14.97)^{* * *}\end{array}$ \\
\hline NEGE & $+\mathrm{ve}$ & $\begin{array}{c}-0.0030 \\
(-0.43) \\
\end{array}$ & $\begin{array}{c}-0.0070 \\
(-0.82) \\
\end{array}$ & $\begin{array}{c}-0.0025 \\
(-0.36) \\
\end{array}$ & $\begin{array}{c}-0.0067 \\
(-0.79) \\
\end{array}$ \\
\hline LOSS & $+\mathrm{ve}$ & $\begin{array}{c}0.0827 \\
(6.33)^{* * *}\end{array}$ & $\begin{array}{c}0.1001 \\
(5.84)^{* * *}\end{array}$ & $\begin{array}{c}0.0812 \\
(6.23)^{* * *}\end{array}$ & $\begin{array}{c}0.0981 \\
(5.66) * * *\end{array}$ \\
\hline FD & + ve & $\begin{array}{l}0.3327 \\
(1.01)\end{array}$ & $\begin{array}{c}0.4938 \\
(0.98)\end{array}$ & $\begin{array}{c}0.3907 \\
(1.20)\end{array}$ & $\begin{array}{l}0.5047 \\
(1.03)\end{array}$ \\
\hline Adjusted $\mathrm{R}^{2}$ & & 0.845 & 0.870 & 0.845 & 0.870 \\
\hline $\begin{array}{l}F \text { test for no fixed } \\
\text { effects }\end{array}$ & & & 0.37 & & 0.40 \\
\hline
\end{tabular}

$\mathrm{FE}=$ the absolute value of the difference between actual earnings and the mean of the individual analyst forecasts scaled by the firm's share price at the end of the fiscal year; REFORM $=1$ if the observation is from the post-reform period, and 0 otherwise; MV = natural log of the firm's total market capitalization at the beginning of the fiscal year; DAYS = natural log of the average number of days by which the forecast precedes the earnings announcement; ANA = the number of analysts who generate a mean forecast of earnings; ESUP $=$ the absolute value of the difference between the current year's EPS and last year's EPS, divided by the firm's share price at the beginning of the fiscal year; NEGE $=1$ if current earnings are below previous earnings, and 0 otherwise; LOSS $=1$ if reported profits are negative, and 0 otherwise; FD = the standard deviation of the individual analysts' forecast scaled by the firm's share price at the end of fiscal year. T-statistics are in parentheses. *** Significant at the 0.01 level; ** Significant at the 0.05 level; *Significant at the 0.10 level 
Table 4

Regression of Forecast Dispersion on REFORM Indicator and Control Variables

$F D_{i t}=\alpha_{0}+\lambda_{1} R E F O R M+\lambda_{2} M V_{i t}+\lambda_{3} D_{A Y S_{i t}}+\lambda_{4} A N A_{i t}+\lambda_{5} E S U P_{i t}+\lambda_{6} N E G E_{i t}+\lambda_{7} L_{O S S_{i t}}+e_{i t}$

\begin{tabular}{|c|c|c|c|c|c|}
\hline & & Model 1 OLS & Model 2 Fixed effects & Model 3 OLS & Model 4 Fixed effects \\
\hline Variable & Predicted & Coefficient (t stats) & Coefficient (t stats) & Coefficient (t stats) & Coefficient (t stats) \\
\hline Constant & & $\begin{array}{c}0.0176 \\
(4.00)^{* * *}\end{array}$ & $\begin{array}{c}0.0576 \\
(3.10)^{* * *}\end{array}$ & $\begin{array}{c}0.0110 \\
(3.55)^{* * *}\end{array}$ & $\begin{array}{c}0.0133 \\
(2.08)^{* *}\end{array}$ \\
\hline REFORM & -ve & $\begin{array}{c}-0.0047 \\
(-2.76)^{* * *}\end{array}$ & $\begin{array}{c}-0.0020 \\
(-1.21)\end{array}$ & $\begin{array}{c}-0.0050 \\
(-2.91)^{* * *}\end{array}$ & $\begin{array}{c}-0.0041 \\
(-2.76)^{* * *}\end{array}$ \\
\hline $\mathrm{MV}$ & -ve & $\begin{array}{c}-0.0020 \\
(-2.93)^{* * *}\end{array}$ & $\begin{array}{c}-0.0091 \\
(-2.46)^{* * *}\end{array}$ & & \\
\hline DAYS & $+\mathrm{ve}$ & $\begin{array}{c}0.0013 \\
(1.49)\end{array}$ & $\begin{array}{c}0.0006 \\
(0.69)\end{array}$ & $\begin{array}{c}0.0012 \\
(1.38)\end{array}$ & $\begin{array}{l}0.0002 \\
(0.19)\end{array}$ \\
\hline ANA & -ve & & & $\begin{array}{l}-0.0009 \\
(-2.24)^{* *}\end{array}$ & $\begin{array}{l}0.0003 \\
(0.48)\end{array}$ \\
\hline ESUP & $+\mathrm{ve}$ & $\begin{array}{c}0.0135 \\
(2.21)^{* *}\end{array}$ & $\begin{array}{c}-0.0040 \\
(-0.64)\end{array}$ & $\begin{array}{l}0.0122 \\
(1.96)^{*}\end{array}$ & $\begin{array}{c}-0.0036 \\
(-0.55)\end{array}$ \\
\hline NEGE & $+\mathrm{ve}$ & $\begin{array}{c}0.0013 \\
(0.75)\end{array}$ & $\begin{array}{l}0.0018 \\
(1.09)\end{array}$ & $\begin{array}{l}0.0017 \\
(0.99)\end{array}$ & $\begin{array}{l}0.0013 \\
(0.79)\end{array}$ \\
\hline LOSS & + ve & $\begin{array}{c}0.0137 \\
(4.39)^{* * *}\end{array}$ & $\begin{array}{l}0.0058 \\
(1.77)^{*}\end{array}$ & $\begin{array}{c}0.0130 \\
(4.11)^{* * *}\end{array}$ & $\begin{array}{c}0.0077 \\
(2.31)^{* *}\end{array}$ \\
\hline Adjusted $\mathrm{R}^{2}$ & & 0.268 & 0.643 & 0.251 & 0.623 \\
\hline $\begin{array}{l}F \text { test for no } \\
\text { fixed effects }\end{array}$ & & & $2.70 * * *$ & & $2.54 * * *$ \\
\hline
\end{tabular}

$\mathrm{FD}=$ the standard deviation of the individual analysts' forecast scaled by the firm's share price at the end of the fiscal year; REFORM $=1$ if the observation is from the post-reform period, and 0 otherwise; $\mathrm{MV}=$ natural log of the firm's total market capitalization at the beginning of the fiscal year; DAYS = natural log of the average number of days by which the forecast precedes the earnings announcement; ANA = the number of analysts who generate mean forecast of earnings; ESUP = the absolute value of the difference between the current year's EPS and last year's EPS, divided by the firm's share price at the beginning of the fiscal year; NEGE $=1$ if current earnings are below previous earnings, and 0 otherwise; LOSS $=1$ if reported profits are negative, and 0 otherwise. T-statistics are in parentheses. *** Significant at the 0.01 level; ** Significant at the 0.05 level; * Significant at the 0.10 level 
Figure 1

Price Discovery Pre-reform v Post-reform
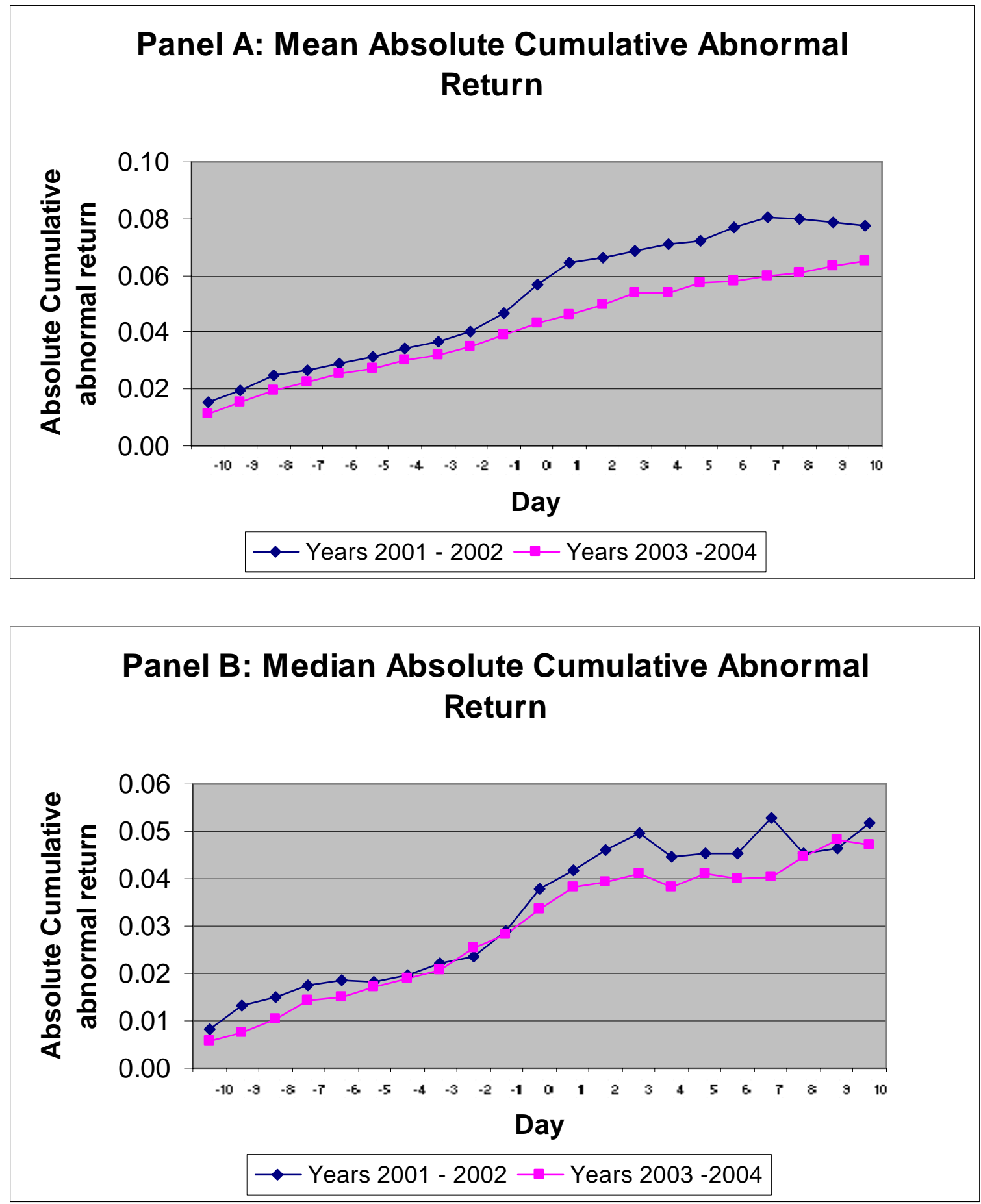

Each panel depicts the absolute cumulative abnormal returns where the accumulation period begins on day 10 and continues through day +10 relative to the earnings announcement date. Abnormal returns are prediction errors from the market model, estimated over 180 trading days prior to the event window period $[-10,+10]$ 
Table 5

Absolute Cumulative Abnormal Returns (ACAR $\left.{ }_{i, t}\right)$ and Pre- and Post-reform Earnings Announcements

\begin{tabular}{|c|c|c|c|c|c|c|c|c|c|c|}
\hline \multirow{2}{*}{$\begin{array}{c}\text { Event } \\
\text { window } \\
\text { period }\end{array}$} & \multicolumn{2}{|c|}{$\operatorname{ACAR}[-2,+3]$} & \multicolumn{2}{|c|}{ ACAR $[-2,+4]$} & \multicolumn{2}{|c|}{ ACAR $[-3,+3]$} & \multicolumn{2}{|c|}{ ACAR $[-3,+4]$} & \multicolumn{2}{|c|}{ ACAR $[-10,+3]$} \\
\hline & Mean & Median & Mean & Median & Mean & Median & Mean & Median & Mean & Median \\
\hline Pre-reform & 0.0584 & 0.0351 & 0.0583 & 0.0340 & 0.0605 & 0.0410 & 0.0632 & 0.0381 & 0.0686 & 0.0497 \\
\hline Post-reform & 0.0415 & 0.0305 & 0.0430 & 0.0313 & 0.0453 & 0.0391 & 0.0472 & 0.0337 & 0.0536 & 0.0410 \\
\hline Difference & 0.0169 & 0.0046 & 0.0153 & 0.0027 & 0.0152 & 0.0019 & 0.0160 & 0.0044 & 0.0150 & 0.0087 \\
\hline p-value & 0.025 & 0.152 & 0.036 & 0.255 & 0.037 & 0.231 & 0.054 & 0.126 & 0.126 & 0.196 \\
\hline
\end{tabular}


Table 6

Panel A: Descriptive Statistics for Control Variables in Regression of Absolute Cumulative Abnormal Returns

\begin{tabular}{|c|c|c|c|c|c|c|c|c|}
\hline & \multicolumn{4}{|c|}{ Mean } & \multicolumn{4}{|c|}{ Median } \\
\hline & Overall & Pre-reform & Post-reform & p-value & Overall & Pre-reform & Post-reform & p-value \\
\hline MB & 2.466 & 2.550 & 2.3813 & 0.745 & 1.400 & 1.450 & 1.4000 & 0.814 \\
\hline LEV & 0.4615 & 0.4729 & 0.4501 & 0.429 & 0.4564 & 0.4564 & 0.4581 & 0.406 \\
\hline MV & 5.1884 & 5.1375 & 5.2392 & 0.600 & 4.9967 & 4.8814 & 5.1459 & 0.397 \\
\hline ESUP & 0.1718 & 0.1569 & 0.1867 & 0.746 & 0.0317 & 0.0380 & 0.0290 & 0.832 \\
\hline LOSS & 0.1371 & 0.1452 & 0.1290 & 0.713 & 0.0000 & 0.0000 & 0.0000 & 0.714 \\
\hline NEGCAR & 0.4135 & 0.4194 & 0.4113 & 0.898 & 0.0000 & 0.0000 & 0.0000 & 0.899 \\
\hline
\end{tabular}

Panel B: Pearson Correlations among the REFORM Indicator and the Control Variables

\begin{tabular}{|c|c|c|c|c|c|c|}
\hline & MB & LEV & MV & EUSP & LOSS & NEGCAR \\
\hline REFORM & -0.2075 & -0.0504 & 0.0335 & 0.0207 & -0.0235 & -0.0082 \\
\hline MB & & $0.2017 * * *$ & $0.2235^{* * *}$ & 0.0578 & 0.0987 & -0.0069 \\
\hline LEV & & & $0.1432 * *$ & -0.0524 & $0.1967 * * *$ & -0.0131 \\
\hline MV & & & & $-0.2588 * * *$ & $-0.1256^{* *}$ & 0.0326 \\
\hline ESUP & & & & & $0.3265 * * *$ & -0.0974 \\
\hline LOSS & & & & & & $0.1694^{*}$ \\
\hline
\end{tabular}

REFORM = 1 if the earnings announcement is from the post-reform period, and 0 otherwise; MB = the ratio of the market to book value of equity at the beginning of the firm's fiscal year; LEV = the ratio of total liabilities to total assets; MV = natural log of the firm's total market capitalization at the beginning of the fiscal year; ESUP = the absolute value of the difference between the current year's EPS and last year's EPS, divided by the firm's share price at the beginning of the fiscal year; LOSS $=1$ if the reported profit is negative, and 0 otherwise; $\mathrm{NEGCAR}_{\mathrm{i}}$ equals 1 if the cumulative abnormal return is negative over the event window period [-10,+3], and 0 otherwise. All pvalues are two-sided. p-values for means are from t-tests of the difference between the pre- and post-reform means. For medians, p-values are from Mann Whitney U tests. $* *$ Correlation is significant at the 0.01 level (2-tailed). * Correlation is significant at the 0.05 level (2-tailed). 
Table 7

Regression of Absolute Cumulative Abnormal Returns on the TREFORM Indicator and Control Variables $\mathrm{ACAR}_{i, t}=\alpha_{0, x}+\lambda_{1} \mathrm{REFORM}+\lambda_{2} \mathrm{MB}_{i t}+\lambda_{3} \mathrm{LEV}_{i t}+\lambda_{4} \mathrm{MV}_{i t}+\lambda_{5} \mathrm{ESUP}_{i t}+\lambda_{6} \mathrm{LOSS}_{i t}+\lambda_{7} \mathrm{NEGCAR}_{i t}+\mathrm{e}_{i, t}$

\begin{tabular}{|c|c|c|c|c|c|c|c|c|c|c|c|}
\hline \multicolumn{2}{|c|}{ Event window period } & \multicolumn{2}{|c|}{$[-2,+3]$} & \multicolumn{2}{|c|}{$[-2,+4]$} & \multicolumn{2}{|c|}{$[-3,+3]$} & \multicolumn{2}{|c|}{$[-3,+5]$} & \multicolumn{2}{|c|}{$[-10,+3]$} \\
\hline Variable & $\begin{array}{l}\text { Predicted } \\
\text { sign }\end{array}$ & OLS & $\begin{array}{c}\text { Fixed } \\
\text { effects }\end{array}$ & OLS & $\begin{array}{c}\text { Fixed } \\
\text { effects }\end{array}$ & OLS & $\begin{array}{c}\text { Fixed } \\
\text { effects }\end{array}$ & OLS & $\begin{array}{c}\text { Fixed } \\
\text { effects }\end{array}$ & OLS & $\begin{array}{c}\text { Fixed } \\
\text { effects }\end{array}$ \\
\hline Intercept & & $\begin{array}{c}0.0587 \\
(3.81)^{* * *}\end{array}$ & $\begin{array}{c}-0.0393 \\
(-0.49) \\
\end{array}$ & $\begin{array}{c}0.0690 \\
(4.60)^{* * *}\end{array}$ & $\begin{array}{c}0.0532 \\
(0.69) \\
\end{array}$ & $\begin{array}{c}0.0595 \\
(4.04)^{* * *}\end{array}$ & $\begin{array}{c}-0.0410 \\
(-0.53) \\
\end{array}$ & $\begin{array}{c}0.0601 \\
(3.54)^{* * *}\end{array}$ & $\begin{array}{c}-0.0463 \\
(-0.51) \\
\end{array}$ & $\begin{array}{c}0.0843 \\
(4.24)^{* * *}\end{array}$ & $\begin{array}{l}0.1056 \\
(0.95)\end{array}$ \\
\hline REFORM & -ve & $\begin{array}{c}-0.0156 \\
(-2.17)^{* *} \\
\end{array}$ & $\begin{array}{c}-0.0153 \\
(-2.28)^{* *}\end{array}$ & $\begin{array}{c}-0.0142 \\
(-2.03)^{* *}\end{array}$ & $\begin{array}{c}-0.0128 \\
(-2.00)^{* *}\end{array}$ & $\begin{array}{c}-0.0104 \\
(-2.04)^{* *}\end{array}$ & $\begin{array}{c}-0.0140 \\
(-2.16)^{* *}\end{array}$ & $\begin{array}{l}-0.0146 \\
(-1.85)^{*}\end{array}$ & $\begin{array}{c}-0.0156 \\
(-2.04)^{* *} \\
\end{array}$ & $\begin{array}{c}-0.0136 \\
(-1.43) \\
\end{array}$ & $\begin{array}{c}-0.0121 \\
(-1.31) \\
\end{array}$ \\
\hline $\mathrm{MB}$ & $+\mathrm{ve}$ & $\begin{array}{l}-0.0016 \\
(-1.69)^{*}\end{array}$ & $\begin{array}{c}-0.0010 \\
(-0.49)\end{array}$ & $\begin{array}{c}-0.0008 \\
(-0.89) \\
\end{array}$ & $\begin{array}{c}0.0019 \\
(1.00) \\
\end{array}$ & $\begin{array}{l}-0.0015 \\
(-1.67)^{*}\end{array}$ & $\begin{array}{c}-0.0012 \\
(-0.63) \\
\end{array}$ & $\begin{array}{c}-0.0016 \\
(-1.59) \\
\end{array}$ & $\begin{array}{c}-0.0014 \\
(-0.61)\end{array}$ & $\begin{array}{c}-0.0006 \\
(-0.47)\end{array}$ & $\begin{array}{c}0.0017 \\
(0.64)\end{array}$ \\
\hline LEV & $+\mathrm{ve}$ & $\begin{array}{l}0.0298 \\
(1.79)^{*}\end{array}$ & $\begin{array}{l}0.0854 \\
(1.93)^{*}\end{array}$ & $\begin{array}{r}0.0215 \\
(1.33) \\
\end{array}$ & $\begin{array}{c}0.0600 \\
(1.43) \\
\end{array}$ & $\begin{array}{l}0.0277 \\
(1.74)^{*}\end{array}$ & $\begin{array}{l}0.0814 \\
(1.91)^{*}\end{array}$ & $\begin{array}{c}0.0408 \\
(2.22)^{* *}\end{array}$ & $\begin{array}{c}0.0713 \\
(1.45) \\
\end{array}$ & $\begin{array}{c}0.0226 \\
(1.03) \\
\end{array}$ & $\begin{array}{l}0.0430 \\
(0.71)\end{array}$ \\
\hline MV & -ve & $\begin{array}{l}-0.0045 \\
(-1.76)^{*}\end{array}$ & $\begin{array}{c}0.0030 \\
(0.27) \\
\end{array}$ & $\begin{array}{c}-0.0056 \\
(-2.25)^{* *}\end{array}$ & $\begin{array}{l}-0.0086 \\
(-0.83) \\
\end{array}$ & $\begin{array}{c}-0.0039 \\
(-1.59) \\
\end{array}$ & $\begin{array}{l}0.0051 \\
(0.49) \\
\end{array}$ & $\begin{array}{c}-0.0044 \\
(-1.55) \\
\end{array}$ & $\begin{array}{c}0.0052 \\
(0.43)\end{array}$ & $\begin{array}{l}-0.0063 \\
(-1.88)^{*}\end{array}$ & $\begin{array}{c}-0.0115 \\
(-0.77) \\
\end{array}$ \\
\hline ESUP & $+\mathrm{ve}$ & $\begin{array}{c}0.0082 \\
(1.51)\end{array}$ & $\begin{array}{l}0.0087 \\
(1.38)\end{array}$ & $\begin{array}{l}0.0099 \\
(1.87)^{*} \\
\end{array}$ & $\begin{array}{c}0.0088 \\
(1.47) \\
\end{array}$ & $\begin{array}{c}0.0093 \\
(1.78)^{*} \\
\end{array}$ & $\begin{array}{c}0.0100 \\
(1.64)\end{array}$ & $\begin{array}{l}0.0111 \\
(1.85)^{*}\end{array}$ & $\begin{array}{c}0.0071 \\
(1.01) \\
\end{array}$ & $\begin{array}{r}0.0095 \\
(1.33) \\
\end{array}$ & $\begin{array}{c}-0.0064 \\
(-0.74) \\
\end{array}$ \\
\hline LOSS & $+\mathrm{ve}$ & $\begin{array}{c}0.0339 \\
(2.95)^{* * *}\end{array}$ & $\begin{array}{c}0.0140 \\
(1.03)\end{array}$ & $\begin{array}{c}0.0259 \\
(2.32)^{* *}\end{array}$ & $\begin{array}{c}0.0067 \\
(0.52)\end{array}$ & $\begin{array}{c}0.0357 \\
(3.24)^{* * *}\end{array}$ & $\begin{array}{l}0.0170 \\
(1.30) \\
\end{array}$ & $\begin{array}{c}0.0317 \\
(2.50)^{* *}\end{array}$ & $\begin{array}{c}-0.0017 \\
(-0.11)\end{array}$ & $\begin{array}{c}0.0413 \\
(2.76)^{* * *}\end{array}$ & $\begin{array}{l}0.0155 \\
(0.84) \\
\end{array}$ \\
\hline NEGCAR & $+\mathrm{ve}$ & $\begin{array}{c}0.0074 \\
(2.08)^{* *}\end{array}$ & $\begin{array}{c}0.0174 \\
(2.30)^{* *}\end{array}$ & $\begin{array}{c}0.0106 \\
(1.48) \\
\end{array}$ & $\begin{array}{c}0.0142 \\
(1.97)^{* *}\end{array}$ & $\begin{array}{c}0.0117 \\
(1.66) \\
\end{array}$ & $\begin{array}{c}0.0141 \\
(1.94)^{* *}\end{array}$ & $\begin{array}{c}0.0093 \\
(1.15) \\
\end{array}$ & $\begin{array}{c}0.0127 \\
(1.53)\end{array}$ & & \\
\hline $\begin{array}{l}\text { Adjusted } \mathrm{R}^{2} \\
\mathrm{~F} \text { test for no } \\
\text { fixed effects }\end{array}$ & & 0.108 & $1.85 * * *$ & 0.092 & $2.11 * * *$ & 0.111 & $1.79 * * *$ & 0.094 & $1.76 * * *$ & 0.073 & $1.49 * *$ \\
\hline $\mathrm{n}$ & & 248 & 248 & 248 & 248 & 248 & 248 & 248 & 248 & 248 & 248 \\
\hline
\end{tabular}

$\mathrm{ACAR}_{\mathrm{i}, \mathrm{t}}=$ the absolute cumulative abnormal return from $\mathrm{t}=-\mathrm{x}$ days before to $\mathrm{t}=+\mathrm{y}$ days after firm $i$ 's annual earnings announcement. REFORM $=1$ if the earnings announcement is from the post-reform period, and 0 otherwise; $\mathrm{MB}=$ the ratio of the market to book value of equity at the beginning of the fiscal year; LEV $=$ the ratio of total liabilities to total assets; MV = natural log of the firm's total market capitalization at the beginning of the fiscal year; ESUP = the absolute value of the difference between the current year's EPS and last year's EPS, divided by the firm's share price at the beginning of the fiscal year; LOSS = 1 if reported profit is negative, and 0 otherwise; NEGCAR $\mathrm{N}_{\mathrm{i}}$ equals 1 if the cumulative abnormal return is negative over the event window period [-10,+3], and 0 otherwise. The coefficients on the regression for each dependent variable are provided with the t-statistics are in parentheses. *** Significant at the 0.01 level; ** Significant at the 0.05 level; $*$ Significant at the 0.10 level. 
Table 8

Regression of Absolute Cumulative Abnormal Returns on the REFORM Indicator and Control Variables $\mathrm{ACAR}_{i, t}=\alpha_{0, x}+\lambda_{1} \mathrm{REFORM}+\lambda_{2} \mathrm{MB}_{i t}+\lambda_{3} \mathrm{LEV}_{i t}+\lambda_{4} \mathrm{MV}_{i t}+\lambda_{5} \mathrm{ESUP}_{i t}+\lambda_{6} \mathrm{LOSS}_{i t}+\lambda_{7} \mathrm{NEGCAR}_{i t}+\mathrm{e}_{i, t}$

\begin{tabular}{|c|c|c|c|c|c|c|c|c|c|}
\hline & & \multicolumn{4}{|c|}{ Small firms } & \multicolumn{4}{|c|}{ Large firms } \\
\hline \multicolumn{2}{|c|}{ Event window period } & \multicolumn{2}{|c|}{$[-2,+3]$} & \multicolumn{2}{|c|}{$[-2,+4]$} & \multicolumn{2}{|c|}{$[-2,+3]$} & \multicolumn{2}{|c|}{$[-2,+4]$} \\
\hline Variable & $\begin{array}{l}\text { Predict } \\
\text { sign }\end{array}$ & OLS & $\begin{array}{c}\text { Fixed } \\
\text { effects }\end{array}$ & OLS & $\begin{array}{c}\text { Fixed } \\
\text { effects }\end{array}$ & OLS & $\begin{array}{c}\text { Fixed } \\
\text { effects }\end{array}$ & OLS & $\begin{array}{c}\text { Fixed } \\
\text { effects }\end{array}$ \\
\hline Intercept & & $\begin{array}{c}0.0801 \\
(2.86)^{* * *}\end{array}$ & $\begin{array}{l}0.0951 \\
(1.86)^{*} \\
\end{array}$ & $\begin{array}{c}0.0820 \\
(2.86) * * *\end{array}$ & $\begin{array}{c}0.1750 \\
(3.35)^{* * *}\end{array}$ & $\begin{array}{c}0.0141 \\
(0.43) \\
\end{array}$ & $\begin{array}{c}0.1630 \\
(1.03) \\
\end{array}$ & $\begin{array}{c}0.0203 \\
(0.66) \\
\end{array}$ & $\begin{array}{c}0.1662 \\
(1.17) \\
\end{array}$ \\
\hline REFORM & -ve & $\begin{array}{c}-0.0202 \\
(-2.15)^{* *}\end{array}$ & $\begin{array}{c}-0.0224 \\
(-2.73)^{* * *}\end{array}$ & $\begin{array}{l}-0.0175 \\
(-1.81)^{*}\end{array}$ & $\begin{array}{c}-0.0175 \\
(-2.09)^{* *}\end{array}$ & $\begin{array}{c}-0.0106 \\
(-0.95)\end{array}$ & $\begin{array}{c}-0.0048 \\
(-0.44)\end{array}$ & $\begin{array}{r}-0.0100 \\
(-0.96)\end{array}$ & $\begin{array}{c}-0.0052 \\
(-0.54)\end{array}$ \\
\hline MB & $+\mathrm{ve}$ & $\begin{array}{c}-0.0026 \\
(-1.19) \\
\end{array}$ & $\begin{array}{c}-0.0037 \\
(-1.56) \\
\end{array}$ & $\begin{array}{c}0.0015 \\
(0.67) \\
\end{array}$ & $\begin{array}{c}0.0027 \\
(1.14) \\
\end{array}$ & $\begin{array}{r}-0.0017 \\
(-1.47) \\
\end{array}$ & $\begin{array}{c}0.0029 \\
(0.86) \\
\end{array}$ & $\begin{array}{c}-0.0018 \\
(-1.59) \\
\end{array}$ & $\begin{array}{r}0.0017 \\
(0.58) \\
\end{array}$ \\
\hline LEV & $+\mathrm{ve}$ & $\begin{array}{c}0.0075 \\
(0.38) \\
\end{array}$ & $\begin{array}{r}-0.0057 \\
(-0.10) \\
\end{array}$ & $\begin{array}{c}0.0064 \\
(0.31) \\
\end{array}$ & $\begin{array}{c}-0.0364 \\
(-0.65) \\
\end{array}$ & $\begin{array}{c}0.0488 \\
(1.53) \\
\end{array}$ & $\begin{array}{c}0.1630 \\
(2.42)^{* *}\end{array}$ & $\begin{array}{c}0.0483 \\
(1.61) \\
\end{array}$ & $\begin{array}{c}0.1559 \\
(2.56)^{* *}\end{array}$ \\
\hline MV & -ve & $\begin{array}{c}-0.0050 \\
(-0.81)\end{array}$ & $\begin{array}{c}0.0164 \\
(1.41) \\
\end{array}$ & $\begin{array}{c}-0.0065 \\
(-1.03) \\
\end{array}$ & $\begin{array}{c}-0.0004 \\
(-0.04)\end{array}$ & $\begin{array}{l}0.0001 \\
(0.00)\end{array}$ & $\begin{array}{c}-0.0343 \\
(-1.54) \\
\end{array}$ & $\begin{array}{c}-0.0004 \\
(-0.08) \\
\end{array}$ & $\begin{array}{c}-0.0334 \\
(-1.66) \\
\end{array}$ \\
\hline ESUP & $+\mathrm{ve}$ & $\begin{array}{c}0.0062 \\
(1.10) \\
\end{array}$ & $\begin{array}{l}0.0099 \\
(1.76)^{*}\end{array}$ & $\begin{array}{c}0.0071 \\
(1.22) \\
\end{array}$ & $\begin{array}{l}0.0115 \\
(1.99)^{*}\end{array}$ & $\begin{array}{l}0.0275 \\
(1.29) \\
\end{array}$ & $\begin{array}{c}0.0004 \\
(0.02) \\
\end{array}$ & $\begin{array}{c}0.0153 \\
(0.76) \\
\end{array}$ & $\begin{array}{c}-0.0168 \\
(-0.76) \\
\end{array}$ \\
\hline LOSS & $+\mathrm{ve}$ & $\begin{array}{l}0.0281 \\
(1.92)^{*}\end{array}$ & $\begin{array}{c}0.0024 \\
(0.14) \\
\end{array}$ & $\begin{array}{c}0.0226 \\
(1.51)\end{array}$ & $\begin{array}{c}-0.0056 \\
(-0.33)\end{array}$ & $\begin{array}{c}0.0288 \\
(1.41)\end{array}$ & $\begin{array}{l}0.0434 \\
(1.92)^{*}\end{array}$ & $\begin{array}{l}0.0213 \\
(1.11)\end{array}$ & $\begin{array}{c}0.0301 \\
(1.47)\end{array}$ \\
\hline NEGCAR & $+\mathrm{ve}$ & $\begin{array}{c}0.0129 \\
(1.33) \\
\end{array}$ & $\begin{array}{c}0.0186 \\
(2.07)^{* *}\end{array}$ & $\begin{array}{c}0.0076 \\
(0.76) \\
\end{array}$ & $\begin{array}{l}0.0167 \\
(1.81)^{*}\end{array}$ & $\begin{array}{c}0.0168 \\
(1.49) \\
\end{array}$ & $\begin{array}{l}0.0209 \\
(1.73)^{*}\end{array}$ & $\begin{array}{l}0.0137 \\
(1.30) \\
\end{array}$ & $\begin{array}{l}0.0135 \\
(1.24) \\
\end{array}$ \\
\hline Adjusted $\mathrm{R}^{2}$ & & 0.073 & & 0.065 & & 0.089 & & 0.054 & \\
\hline $\begin{array}{l}\text { F test for no fixed } \\
\text { effects }\end{array}$ & & & $2.68 * * *$ & & $2.68 * * *$ & & $1.61 * *$ & & $1.97 * * *$ \\
\hline $\mathrm{n}$ & & 124 & 124 & 124 & 124 & 124 & 124 & 124 & 124 \\
\hline
\end{tabular}

$\mathrm{ACAR}_{\mathrm{i}, \mathrm{t}}=$ the absolute cumulative abnormal return from $\mathrm{t}=-\mathrm{x}$ days before to $\mathrm{t}=+\mathrm{y}$ days after firm $i$ 's annual earnings announcement. $\mathrm{REFORM}=$ 1 if earnings announcement is from the post-reform period, and 0 otherwise; $\mathrm{MB}=$ the ratio of the market to book value of equity at the beginning of the fiscal year; LEV = the ratio of total liabilities to total assets; MV = natural log of the firm's total market capitalization at the beginning of the fiscal year; ESUP = the absolute value of the difference between the current year's EPS and last year's EPS, divided by the firm's share price at the beginning of the fiscal year; LOSS $=1$ if reported profit is negative, and 0 otherwise; NEGCAR $\mathrm{i}_{\mathrm{i}}$ equals 1 if the cumulative abnormal return is negative over the event window period $[-10,+3]$. The coefficients on the regression for each dependent variable are provided with the $t$-statistics are in parentheses. *** Significant at the 0.01 level; ** Significant at the 0.05 level; $*$ Significant at the 0.10 level 
